Check for updates

Cite this: RSC Adv., 2018, 8, 39394

\title{
Visible colorimetric fluoride and hydroxide sensing by asymmetric tris-urea receptors: combined experimental and theoretical studies $\dagger$
}

\begin{abstract}
Ruyu Wang, Xi Shu, Yu Fan, Shoujian Li, Yongdong Jin and Chao Huang (iD *
A series of asymmetric tris-urea receptors with electron withdrawing group (EWG) or electron donating group (EDG), L1-L4, were synthesized and characterized by high resolution mass spectroscopy (HRMS), nuclear magnetic resonance spectroscopy (NMR) and single-crystal X-ray diffraction (XRD) techniques. Receptors with EWG substituent showed different visible colorimetric response to fluoride and hydroxide anions. Binding studies toward various monovalent anions were performed by UV-Vis and NMR titration experiments. The experimental results revealed that these tris-urea receptors underwent stepwise deprotonation of the three $\mathrm{N}-\mathrm{H}$ protons in the presence of varying excess of fluoride and hydroxide anions. This phenomenon was signalled by the development of vivid colours. These findings were also supported by density functional theory (DFT) and time-dependent DFT (TDDFT) theoretical calculations. DFT studies proved that the deprotonation of receptors with EWG substituent was energetically favourable in comparison with the receptor containing EDG substituent. TDDFT calculations for molecular orbital distribution, oscillator strength, and the electron transition process between the ground state and excited state of receptors and their corresponding deprotonated receptors were performed to elucidate the different absorption properties.
\end{abstract}

Received 8th September 2018
Accepted 19th November 2018

DOI: $10.1039 / c 8 r a 07495 j$

rsc.li/rsc-advances

\section{Introduction}

Anions play important roles in many chemical, catalysis, environmental science, and biological systems. ${ }^{1-3}$ For example, fluoride is indispensable in biology, environmental, industrial research. Fluoride is a common composition in bone, ${ }^{4}$ hypnotics, anesthetics, psychiatric medicines, ${ }^{5}$ poisons, and nerve gas chemical weapons. Generally, fluoride is also a pollutant in underground water. ${ }^{6}$ Much work so far has focused on designing and developing sensory molecules for recognition and detection of anionic compounds., ${ }^{7,8}$

Nowadays, an interesting approach in the use of urea based receptors as a hydrogen bond donor in the recognition of anions have attracted much attention..$^{9-13}$ In particular, considerable research efforts have been devoted to the designation of receptors containing one ureido subunit, which are good at selectively recognizing fluoride. ${ }^{\mathbf{1 4 - 1 6}}$ In particular, two equivalents of $\mathrm{F}^{-}$ions could induce the solution colour of 1,3bis(4-nitrophenyl)urea change from colourless to orange-red. ${ }^{\mathbf{4}}$ In addition, a benzophenone group and a nitrophenyl group

College of Chemistry, Sichuan University, No. 29 Wangjiang Road, Chengdu 610064, Sichuan, PR China.E-mail: chuang@scu.edu.cn

$\dagger$ Electronic supplementary information (ESI) available: Characterizations, NMR data, coordinates of the computed structures and other materials. CCDC 1574164-1574166. For ESI and crystallographic data in CIF or other electronic format see DOI: $10.1039 / \mathrm{c} 8 \mathrm{ra07495j}$ substituted urea can detect $\mathrm{F}^{-}$ion with naked eye and the colour changes from colourless to yellow/orange. ${ }^{17}$ Moreover, receptors containing two ureido subunits have also been reported and represented good selectivity for recognition toward fluoride. For instance, Nam et al. found that the naphthalene derived bis-urea displayed an individual colour change only when treated with fluoride ion. ${ }^{\mathbf{1 8 , 1 9}}$ Das et al. reported colorimetric receptors for selectively sensing fluoride ion. The colour of these receptors, including two urea subunits linked to an anthraquinone moiety, changed from pale yellow to pale red upon addition of $\mathrm{F}^{-} \cdot{ }^{20}$ Kondo et al. presented a series of bis-urea based on 2,2-binaphthalene containing various alkyl and aryl substituents represent a strong anion binding ability, particularly, the receptor with $n$-butyl substituent showed a stronger affinity with fluoride. ${ }^{21}$ In 2012 , Chauhan et al. investigated the colorimetric responses of four (thio)ureas based on 2,2diaminoazo-benzene, these receptors exhibited significant naked-eye colorimetric change on the addition of $\mathrm{F}^{-} \cdot{ }^{22}$ In addition, tris(2-aminoethyl) amine (tren) based tripodal urea or thiourea receptors for recognition and separation of anions has been intensively investigated. ${ }^{23-26}$

For instance, early in 2005, Custelcean et al. reported a coordination polymer host functionalized with tren-based trisurea, which provided a coordinatively saturated environment for sulfate dianion through ureido hydrogen bonds. ${ }^{27}$ Two years later, Ganguly and Das et al. pointed out a tren-based tris-urea receptor showed preferential binding affinity with phosphate 


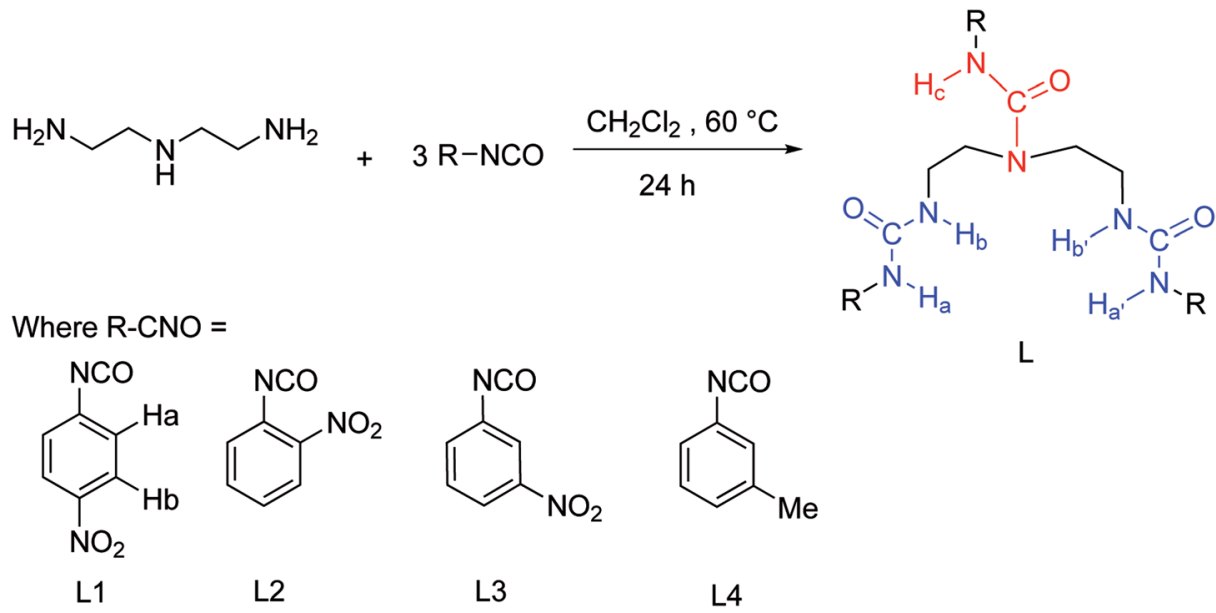

Scheme 1 Synthetic route of receptors L1-L4.

or sulfate anion. ${ }^{28}$ In 2009 , Ghosh et al. studied the anionbinding properties of a pentafluorophenyl substituted trenbased tris-urea, which not only displayed a particular selectivity toward phosphate anion but also showed a strong affinity with fluoride, encapsulating one $\mathrm{F}^{-}$ion into the $C_{3 \mathrm{v}}$-symmetric cleft of the receptor. ${ }^{29}$ Following this work, they found that this $C_{3 \mathrm{v}}$ tripodal urea had special binding ability with the toxic and biologically relevant $\mathrm{HAsO}_{4}{ }^{2-}$ anion. ${ }^{30}$ More interestingly, they discovered the tren-based 3-cyanophenyl-substituted tripodal urea receptor was capable of fixing atmospheric carbon dioxide, which was transformed into carbonate and further encapsulated by this receptor forming a capsular. ${ }^{31}$ In 2009, Custelcean et al. reported crystallization of self-assembled capsules functionalized with urea hydrogen-bonding groups as a means for selective separation of sulfate anion by a tren-based tripodal tris-urea. ${ }^{32}$ In 2011, Hossain et al. identified a seven coordinate complex crystal structure of a hydrogen sulfate anion surrounded by a $p$-cyanophenyl derived tren urea receptor. ${ }^{33}$ Subsequently, they found the same receptor was shown to bind a fluoride ion strongly compared to other halide anions without any visible colour changes of the solution. ${ }^{34}$ In 2012, Gale et al. reported three indolyl substituted tren ureido receptors, which were able to bind sulphate in $10 \%$ aqueous DMSO- $d_{6}$ solution with very high stability constant. ${ }^{35}$ In the same year, Das et al. investigated a tren-based tris-urea receptor with $m$-nitrophenyl terminal as a potential molecular system, which not only can efficiently capture and fix $\mathrm{CO}_{2}$ from atmosphere as stable crystals in air of a carbonate anion encapsulated molecular capsule and can encapsulate a sulfate anion $\left(\mathrm{SO}_{4}{ }^{2-}\right)$ within a dimeric capsular with self-assemble of the receptor. ${ }^{36}$ Next year, they systematically studied all of the isomers of nitrophenyl functionalized tripodal tris-urea, in particular, oxoanions with different size could be encapsulated into a dimeric capsular by the para-isomer. ${ }^{37}$ In 2016 , Wu et al. reported a tetraphenylethene (TPE) derived tripodal tris-urea receptor, which demonstrated a notable emission enhancement in the presence of orthophosphate anion $\left(\mathrm{PO}_{4}{ }^{3-}\right) .^{38}$ Freshly, Hossain et al. described a sulfate and fluoride differential receptor, which is based on a tren scaffold with tris(thioureas). ${ }^{39}$ Overall, the tren- based $C_{3 \mathrm{v}}$-symmetric tripodal tris-urea receptors exhibited remarkably anion binding ability because of the tripodal conformation made it possible to form a spheroidal cavities to encapsulate anions of perfect fitting, however, asymmetric trisurea receptors have been rarely studied so far.

Very recently, we have reported a symmetry $o$-phenylendiamine bis-urea with considerable binding strength towards $\mathrm{Cl}^{-}$ or $\mathrm{Br}^{-}{ }^{40} \mathrm{Here}$, to enrich the library of tris-urea receptors, we would like to report four novel asymmetric tris-urea receptors L1-L4 with the capability of discriminating both fluoride and hydroxide anions (Scheme 1). Compared with mono urea and bis-urea receptors, these receptors with two flexible symmetric urea units $\left(\mathrm{N}-\mathrm{H}_{\mathrm{a}}\right.$ and $\left.\mathrm{N}-\mathrm{H}_{\mathrm{b}}\right)$ and one asymmetric urea unit $(\mathrm{N}-$ $\mathrm{H}_{\mathrm{c}}$ ) contain more H-bond binding sites toward anions. Anionbinding properties for these receptors were examined by naked eye detection, UV-Vis spectroscopy, and NMR experiments. It was found that the receptors L1-L3 represented a vivid colour change upon the addition of fluoride and hydroxide anions. Moreover, we performed density functional theory (DFT) and time-dependent DFT (TDDFT) theoretical calculations to elucidate the binding mode of the receptors in DMSO solution and to analyse the excitation state of receptors and their corresponding anions, respectively. Both experimental and theoretical studies indicated that the stepwise deprotonation of the urea $\mathrm{N}-\mathrm{H}$ gave rise to the development of discernible colours.

\section{Experimental}

\section{Materials and general methods}

Unless otherwise stated, all chemical reagents were obtained from commercial suppliers and used without further purification. All of the solvents used were purified and dried by standard methods prior to use.

The ${ }^{1} \mathrm{H}$ NMR (400 MHz) and ${ }^{13} \mathrm{C}$ NMR $(100 \mathrm{MHz})$ spectra were recorded on a Bruker AV III $400 \mathrm{MHz}$ spectrometer with DMSO- $d_{6}$ as the solvent and tetramethylsilane (TMS) as an internal reference. UV-Vis absorption spectra were determined on a PERSEE TU-1810 spectrophotometer. FT-IR spectra (400- 
$\left.4000 \mathrm{~cm}^{-1}\right)$ were recorded on a Nicolet 670 spectrometer with a $(\mathrm{S} / \mathrm{N})$ of $40000: 1$ in the solid state (KBr pellets). Single crystal X-ray diffraction (XRD) data were harvested on an Agilent Technologies Gemini single-crystal diffractometer. High resolution mass spectra (HRMS) were carried out on a Shimadzu LCMS-IT-TOF (ESI) spectrometer.

\section{Synthesis}

L1. In a $250 \mathrm{~mL}$ of round bottom flask, diethylenetriamine (0.32 mL, $2.97 \mathrm{mmol}$ ) dissolved in $100 \mathrm{~mL}$ of dry $\mathrm{CH}_{2} \mathrm{Cl}_{2}$ was dropwise added into a solution of $20 \mathrm{~mL}$ of dry $\mathrm{CH}_{2} \mathrm{Cl}_{2}$ containing $p$-nitrobenzene isocyanate $(1.64 \mathrm{~g}, 9.98 \mathrm{mmol})$ with vigorous stirring. Subsequently, the reaction mixture was allowed to reflux for $24 \mathrm{~h}$. A yellowish solid was collected by filtration. This solid was washed using $\mathrm{CH}_{2} \mathrm{Cl}_{2}(3 \times 70 \mathrm{~mL})$, a mixture solvent $\left(\mathrm{CH}_{2} \mathrm{Cl}_{2} / \mathrm{THF}=4: 1,3 \times 70 \mathrm{~mL}\right)$, and diethyl ether $(3 \times 70 \mathrm{~mL})$, separately. The solid was dried in vacuo overnight to afford $1.52 \mathrm{~g}(85.6 \%)$ of compound L1 as a light brown powder. Mp: $239.1-240.6{ }^{\circ} \mathrm{C}$. FT-IR $\left(\mathrm{KBr}, \mathrm{cm}^{-1}\right)$ : 3338.9, 1679.2, 1605.8, 1558.5, 1500.7, 1329.8. ${ }^{1} \mathrm{H}$ NMR $(400 \mathrm{MHz}$, DMSO- $\left.d_{6}\right): \delta=9.42(\mathrm{~s}, 2 \mathrm{H}), 9.23(\mathrm{~s}, 1 \mathrm{H}), 8.10(\mathrm{t}, J=9.9 \mathrm{~Hz}, 6 \mathrm{H})$, $7.76(\mathrm{~d}, J=8.9 \mathrm{~Hz}, 2 \mathrm{H}), 7.59(\mathrm{~d}, J=8.9 \mathrm{~Hz}, 4 \mathrm{H}), 6.60(\mathrm{t}, J=$ $5.8 \mathrm{~Hz}, 2 \mathrm{H}), 3.51(\mathrm{t}, J=6.5 \mathrm{~Hz}, 4 \mathrm{H}) \mathrm{ppm} .{ }^{13} \mathrm{C}$ NMR $(100 \mathrm{MHz}$, DMSO- $\left.d_{6}\right): \delta=154.99,154.67,147.34,146.94,140.72,140.48$, 125.09, 124.70, 118.13, 116.95, 46.63, 40.15-38.89, 38.19 ppm. HRMS (ESI ${ }^{+}$): calcd for $\mathrm{C}_{25} \mathrm{H}_{25} \mathrm{~N}_{9} \mathrm{O}_{9} \mathrm{Na}[\mathrm{M}+\mathrm{Na}]^{+} 618.1673$; found 618.1678.

L2. Receptor L2 was synthesized following the procedure of receptor $\mathrm{L} 1$ except that the $o$-nitrobenzene isocyanate was used in place of $p$-nitrobenzene isocyanate. Yellowish solid: yield 74.5\%. Mp: 208.4-209.5 ${ }^{\circ} \mathrm{C}$. FT-IR (KBr, $\mathrm{cm}^{-1}$ ): 3394.8 1706.2, 1610.3, 1584.6, 1500.6, 1453.8, 955. ${ }^{1} \mathrm{H}$ NMR (400 MHz, DMSO$\left.d_{6}\right): \delta=9.44(\mathrm{~s}, 1 \mathrm{H}), 9.38(\mathrm{~s}, 2 \mathrm{H}), 8.26(\mathrm{~d}, J=8.4 \mathrm{~Hz}, 2 \mathrm{H}), 8.02$ (dd, $J=8.4,1.3 \mathrm{~Hz}, 2 \mathrm{H}), 7.95-7.89(\mathrm{~m}, 2 \mathrm{H}), 7.69(\mathrm{~s}, 2 \mathrm{H}), 7.63-$ 7.57 (m, 3H), 7.17-7.09 (m, 3H), $3.48(\mathrm{t}, J=5.7 \mathrm{~Hz}, 4 \mathrm{H}) \mathrm{ppm} .{ }^{13} \mathrm{C}$ NMR (100 MHz, DMSO- $\left.d_{6}\right): \delta=154.54,154.25,139.12,136.91$, 135.66, 135.09, 134.90, 134.37, 125.28, 125.07, 123.18, 122.47, 122.09, 121.51, 47.16, 40.15-38.90, 37.99 ppm. HRMS (ESI ${ }^{+}$): calcd for $\mathrm{C}_{25} \mathrm{H}_{25} \mathrm{~N}_{9} \mathrm{O}_{9} \mathrm{Na}[\mathrm{M}+\mathrm{Na}]^{+}$618.1673; found 618.1682.

L3. Receptor L3 was synthesized following the procedure of receptor $\mathrm{L} 1$ except that the $m$-nitrobenzene isocyanate was used in place of $p$-nitrobenzene isocyanate. Light brown solid: yield 54.1\%. Mp: $242.8-244.0{ }^{\circ} \mathrm{C}$. FT-IR (KBr, $\mathrm{cm}^{-1}$ ): 3366.6, 3096.5, 1666.7, 1601.4, 1526.5, 1481.8, 1247.6, 737.0, 677.5. ${ }^{1} \mathrm{H}$ NMR $\left(400 \mathrm{MHz}, \mathrm{DMSO}-d_{6}\right): \delta=9.23(\mathrm{~d}, J=6.2 \mathrm{~Hz}, 3 \mathrm{H}), 8.58(\mathrm{~s}, 1 \mathrm{H})$, $8.51(\mathrm{~s}, 2 \mathrm{H}), 7.97(\mathrm{~d}, J=8.2 \mathrm{~Hz}, 1 \mathrm{H}), 7.73(\mathrm{t}, J=8.5 \mathrm{~Hz}, 3 \mathrm{H}), 7.63$ $(\mathrm{d}, J=8.2 \mathrm{~Hz}, 2 \mathrm{H}), 7.46(\mathrm{q}, J=8.1 \mathrm{~Hz}, 3 \mathrm{H}), 6.53(\mathrm{~d}, J=7.3 \mathrm{~Hz}$, $2 \mathrm{H}), 3.49(\mathrm{t}, J=6.5 \mathrm{~Hz}, 4 \mathrm{H}) \mathrm{ppm} .{ }^{13} \mathrm{C}$ NMR (100 MHz, DMSO- $\left.d_{6}\right)$ : $\delta=155.56,155.03,148.06,147.82,142.00,141.60,129.85$, $129.45,124.89,123.73,115.90,115.62,113.04,111.70,46.76$, 40.15-38.89, 38.35 ppm. HRMS (ESI ${ }^{+}$): calcd for $\mathrm{C}_{25} \mathrm{H}_{25} \mathrm{~N}_{9} \mathrm{O}_{9} \mathrm{Na}$ $[\mathrm{M}+\mathrm{Na}]^{+}$618.1673; found 618.1671.

L4. Receptor L4 was synthesized following the procedure of receptor L1 except that the $m$-methylbenzene isocyanate was used in place of $p$-nitrobenzene isocyanate. The crude products were recrystallized from ethanol to afford compound L4 (yield
76.3\%) as a colourless crystalline powder. Mp: $211.1-212.6{ }^{\circ} \mathrm{C}$. FT-IR (KBr, $\left.\mathrm{cm}^{-1}\right)$ : 3326.0, 3252.8, 3034.30, 1551.9, 1484.6, 1440.9, 1289.0, 1245.7, 1137.32, 898.7. ${ }^{1} \mathrm{H}$ NMR $(400 \mathrm{MHz}$, DMSO- $\left.d_{6}\right): \delta=8.75(\mathrm{~s}, 1 \mathrm{H}), 8.61(\mathrm{~s}, 2 \mathrm{H}), 7.46(\mathrm{~d}, J=8.6 \mathrm{~Hz}, 1 \mathrm{H})$, $7.40(\mathrm{~s}, 1 \mathrm{H}), 7.28(\mathrm{~s}, 2 \mathrm{H}), 7.17(\mathrm{~d}, J=8.3 \mathrm{~Hz}, 2 \mathrm{H}), 7.10(\mathrm{td}, J=7.8$, $3.8 \mathrm{~Hz}, 3 \mathrm{H}), 6.74(\mathrm{dd}, J=11.7,7.5 \mathrm{~Hz}, 3 \mathrm{H}), 6.33(\mathrm{t}, J=5.3 \mathrm{~Hz}$, 2H), 3.28-3.21 (m, 4H), 2.24 (s, 9H) ppm. ${ }^{13} \mathrm{C}$ NMR (100 MHz, DMSO- $\left.d_{6}\right): \delta=155.95,155.11,140.64,140.25,137.80,137.37$, $128.54,128.20,122.40,122.05,119.96,118.47,116.45,115.10$, 47.08, 40.15-38.57, 21.30, 21.24 ppm. HRMS (ESI ${ }^{+}$): calcd for $\mathrm{C}_{28} \mathrm{H}_{35} \mathrm{~N}_{6} \mathrm{O}_{3}[\mathrm{M}+\mathrm{H}]^{+}$503.2771; found 503.2771.

\section{UV-Vis absorption spectra}

A stock solution of receptors L1-L4 ([L] $\left.=5.0 \times 10^{-5} \mathrm{M}\right)$ were prepared with DMSO solution and used in the preparation of titration solution by appropriate dilution. The solution of the guest anions in the order of $10^{-2}(\mathrm{M})$ was also prepared in DMSO solution. Titration of receptors L1-L4 was carried out by the addition of a required amount of standard solution of the anion. All anions $\left(\mathrm{F}^{-}, \mathrm{Cl}^{-}, \mathrm{Br}^{-}, \mathrm{I}^{-}, \mathrm{H}_{2} \mathrm{PO}_{4}{ }^{-}, \mathrm{HSO}_{4}{ }^{-}, \mathrm{CH}_{3} \mathrm{COO}^{-}\right.$, $\mathrm{NO}_{3}{ }^{-}, \mathrm{OH}^{-}$and $\mathrm{ClO}_{4}{ }^{-}$) were used as their tetra- $n$-butylammonium (TBA) salts except $\left[\mathrm{NH}_{4}\right]\left[\mathrm{ReO}_{4}\right]$.

\section{NMR titration}

${ }^{1} \mathrm{H}$ NMR titration was conducted in DMSO- $d_{6}$ solution and the changes in the chemical shifts were examined by recording the spectrum at room temperature. The initial concentration of receptors was $5.0 \times 10^{-3} \mathrm{M}$. Stock solutions of the anion $(0.5 \mathrm{M}$, TBA salt or $\left[\mathrm{NH}_{4}\right]\left[\mathrm{ReO}_{4}\right]$ ) were prepared by dissolving the salt in DMSO- $d_{6}$ solution. The requisite number of NMR samples was prepared by adding increasing amounts of the anion solution $(0-50 \mu \mathrm{L})$ to $500 \mu \mathrm{L}$ of the receptor solution.

\section{X-ray crystallography}

Crystals suitable for X-ray diffraction (XRD) were obtained for L1-L3. Single crystal XRD data for L1-L3 were collected on an Agilent Gemini, Dual, $\mathrm{Cu}$ at zero, EosS2 diffractometer equipping with a graphite-monochromated $\mathrm{Cu} \mathrm{K} \alpha(\lambda=0.154184 \mathrm{~nm})$ radiation. The intensity data collected by the $\omega$ scan technique. Within Olex $2,{ }^{41}$ the structure was solved with the ShelXT ${ }^{42}$ structure solution program using Direct Methods and refined with the ShelXL ${ }^{43}$ refinement package by least-squares minimization. X-ray crystallographic information data (CIFs) is available with the CCDC deposition with numbers 1574166 (L1·0.5 ( $\left.\left.\mathrm{Et}_{2} \mathrm{O}\right)\right), 1574164(\mathrm{~L} 2)$ and 1574165 (L3·DMSO) for this paper.

Crystal data for $\mathrm{L1} \cdot 0.5\left(\mathrm{Et}_{2} \mathrm{O}\right) \cdot \mathrm{C}_{27} \mathrm{H}_{28.22} \mathrm{~N}_{9} \mathrm{O}_{9.5},(M=632.59 \mathrm{~g}$ $\mathrm{mol}^{-1}$ ), triclinic, space group $P \overline{1}$ (no. 2), $a=7.1240(4) \AA, b=$

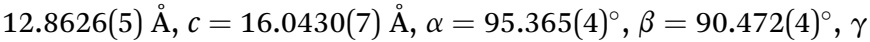
$=101.742(4)^{\circ}, V=1432.45(11) \AA^{3}, Z=2, T=296.31(10) \mathrm{K}, \mu(\mathrm{Cu}$ $\left.\mathrm{K}_{\alpha}\right)=0.962 \mathrm{~mm}^{-1}, D_{\text {calc }}=1.462 \mathrm{~g} \mathrm{~cm}^{-3}, 15706$ reflections measured $\left(9.384^{\circ} \leq 2 \Theta \leq 145.308^{\circ}\right), 5559$ unique $\left(R_{\text {int }}=0.0283\right.$, $\left.R_{\text {sigma }}=0.0245\right)$ which were used in all calculations. The final $R_{1}$ was $0.0751(I>2 \sigma(I))$ and $w R_{2}$ was 0.2378 (all data).

Crystal data for $\mathbf{L} 2 . \mathrm{C}_{25} \mathrm{H}_{25} \mathrm{~N}_{9} \mathrm{O}_{9},\left(M=595.53 \mathrm{~g} \mathrm{~mol}^{-1}\right)$, triclinic, space group $P \overline{1}$ (no. 2), $a=5.8865(2) \AA, b=14.2293(7)$ 
$\AA, \quad c=16.8469(8) \AA, \alpha=75.358(4)^{\circ}, \beta=87.692(3)^{\circ}, \gamma=$ 82.114(4) $)^{\circ}, V=1352.35(11) \AA^{3}, Z=2, T=296.4(7) \mathrm{K}, \mu\left(\mathrm{Cu} \mathrm{K}_{\alpha}\right)=$ $0.970 \mathrm{~mm}^{-1}, D_{\text {calc }}=1.463 \mathrm{~g} \mathrm{~cm}^{-3}, 14966$ reflections measured $\left(9.434^{\circ} \leq 2 \Theta \leq 145.344^{\circ}\right), 5247$ unique $\left(R_{\text {int }}=0.0391, R_{\text {sigma }}=\right.$ $0.0303)$ which were used in all calculations. The final $R_{1}$ was $0.0561(I>2 \sigma(I))$ and $\mathrm{w}_{2}$ was 0.1672 (all data).

Crystal data for L3.DMSO. $\mathrm{C}_{27} \mathrm{H}_{31} \mathrm{~N}_{9} \mathrm{O}_{10} \mathrm{~S},(M=673.67 \mathrm{~g}$ mol $^{-1}$ ), triclinic, space group $P \overline{1}$ (no. 2), $a=10.7261$ (5) $\AA, b=$ 12.0465(6) $\mathrm{A}, c=14.5821(5) \AA, \alpha=83.686(3)^{\circ}, \beta=74.878(4)^{\circ}, \gamma$ $=79.380(4)^{\circ}, V=1783.98(14) \AA^{3}, Z=2, T=296.31(10) \mathrm{K}, \mu(\mathrm{Cu}$ $\left.\mathrm{K}_{\alpha}\right)=1.347 \mathrm{~mm}^{-1}, D_{\text {calc }}=1.254 \mathrm{~g} \mathrm{~cm}^{-3}, 19863$ reflections measured $\left(8.654^{\circ} \leq 2 \Theta \leq 145.346^{\circ}\right), 6937$ unique $\left(R_{\text {int }}=0.0297\right.$, $R_{\text {sigma }}=0.0230$ ) which were used in all calculations. The final $R_{1}$ was $0.0644(I>2 \sigma(I))$ and $w R_{2}$ was 0.2026 (all data).

\section{Theoretical studies}

All of the calculations were performed using the Gaussian 09 program. ${ }^{44}$ The geometries were optimized by means of the M06-2X functional ${ }^{45}$ with the basis set employing 6-311G(d,p) ${ }^{46}$ for all atoms using the polarized continuum model (PCM) in dimethylsulfoxide (DMSO) media. ${ }^{\mathbf{4 7}, 48}$ Frequency computations were performed at the same theoretical levels to ensure that the structures found correspond to a local minimum on the potential energy surface. The single point energy in DMSO solution was calculated according to the M06-2X/6$311+\mathrm{G}(\mathrm{d}, \mathrm{p})^{\mathbf{4 9 , 5 0}}$ level for the geometry optimized above. In addition, the excitation energy, oscillator strength and main contributions of 10 lowest excited states were investigated using time-dependent DFT (TDDFT) calculations with the PBE0 ${ }^{51}$ function in combination with the def2-TZVP ${ }^{49}$ basis set based on the optimized geometry. All TDDFT calculations were carried out under the PCM in DMSO solvent. Charge transfer, electron (EDD) and hole (HDD) density distribution maps have been carried out with Multiwfn program. ${ }^{52}$ The visualization of the molecular orbitals, EDD and HDD maps is performed by using the Visual Molecular Dynamics (VMD) program..$^{53}$

\section{Results and discussion}

The tris-urea receptors L1-L4 were prepared by the facile condensation reaction of diethylenetriamine with the corresponding isocyanate (Scheme 1). These receptors were further characterized by ${ }^{1} \mathrm{H}$ NMR, ${ }^{13} \mathrm{C}$ NMR, FT-IR and HRMS spectroscopy techniques and detailed characterization data were provided in the ESI. $\dagger$ The anion sensing property of the receptors was assessed using naked eye detection, UV-Vis, ${ }^{1} \mathrm{H}$ NMR experiments and theoretical studies.

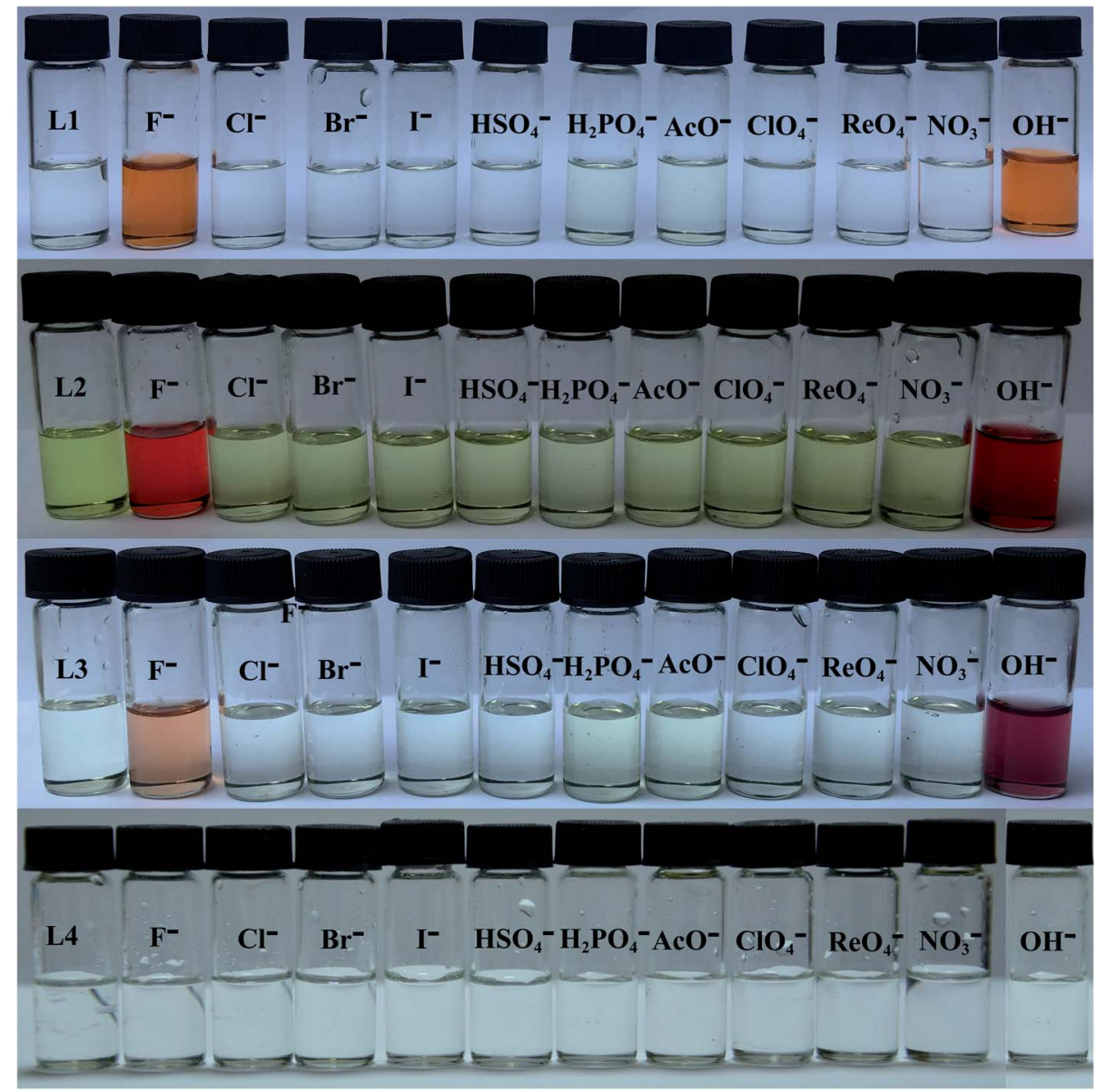

Fig. 1 Naked-eye visible color changes observed for receptors $L 1-L 4$ in DMSO solution $\left([L]=1.0 \times 10^{-3}\right.$ M) on the addition of 10 equivalents of various anions. 


\section{Naked-eye detection experiment}

The sensing of receptors L1-L4 for simple anions such as $\mathrm{F}^{-}$, $\mathrm{Cl}^{-}, \mathrm{Br}^{-}, \mathrm{I}^{-}$, and more complicated anions like $\mathrm{H}_{2} \mathrm{PO}_{4}{ }^{-}, \mathrm{HSO}_{4}{ }^{-}$, $\mathrm{CH}_{3} \mathrm{COO}^{-}, \mathrm{NO}_{3}{ }^{-}, \mathrm{ClO}_{4}{ }^{-}, \mathrm{OH}^{-}$and $\mathrm{ReO}_{4}{ }^{-}$(TBA salts or $\mathrm{NH}_{4} \mathrm{ReO}_{4}$ ) in DMSO solution were detected visually. Addition of 10 equivalents of TBAF into DMSO solution of receptors L1-L3 caused drastic vivid colour changes, specifically, from colourless to orange for $\mathrm{L} 1$, from yellow to red for $\mathrm{L} 2$, and from pale yellow to light orange for L3, which were clearly visible to the naked-eye as depicted in Fig. 1. On the other hand, in the case of $\mathrm{OH}^{-}$, the solution colour changed from colourless to orange for L1, from yellow to dark purple for L2, and from pale yellow to purple for L3, as showed in Fig. 1. In contrast, receptor L4 with an EDG substituent on the meta position of a phenyl ring represented no colour changes upon addition of the same amount of TBAF and TBAOH, as depicted in Fig. 1. It should be noted that $\mathrm{F}^{-}$and $\mathrm{OH}^{-}$ions can readily be discriminated with the naked eye by these asymmetric tris-urea receptors with EWG. While such phenomenon is not found in tren-based tris-urea receptors reported previously. Although some tris-urea receptors displayed significant strong binding affinity toward fluoride anion in solution, they provided non visible colour response to $\mathrm{F}^{-}$or $\mathrm{OH}^{-}$ions, such as quinolinyl-functionalized tripodal tris-urea receptor, ${ }^{54}$ 4-pyridyl-functionalized trisurea, ${ }^{55}$ pentafluorophenyl-substituted tris-urea, ${ }^{29}$ nitrophenyl functionalized tris-urea ${ }^{36,37}$ and $p$-cyanophenyl substituted trisurea. $^{34}$ In addition, even though a series of mesitylene functionalized tris-urea receptors displayed a vivid colorimetric response to $\mathrm{F}^{-}$and $\mathrm{OH}^{-}$anions, from colourless to reddish yellow, these tripodal urea receptors could not distinguish $\mathrm{OH}^{-}$ and $\mathrm{F}^{-}$by naked-eye in their experimental system. ${ }^{56}$

On the other hand, with respect to other anions $\left(\mathrm{Cl}^{-}, \mathrm{Br}^{-}, \mathrm{I}^{-}\right.$, $\mathrm{H}_{2} \mathrm{PO}_{4}{ }^{-}, \mathrm{HSO}_{4}{ }^{-}, \mathrm{CH}_{3} \mathrm{COO}^{-}, \mathrm{NO}_{3}{ }^{-}, \mathrm{ClO}_{4}{ }^{-}$and $\mathrm{ReO}_{4}{ }^{-}$), all of the receptors $\mathrm{L} 1-\mathrm{L} 4$ gave no significant changes in colour. Since the colours changed with the addition of 10 equivalents of $\mathrm{F}^{-}$or $\mathrm{OH}^{-}$ to a solution of receptor L1-L3 (1 mM), we further investigated whether if the receptors can detect $\mathrm{OH}^{-}$and $\mathrm{F}^{-}$ions at a lower concentration with naked-eye vision. As showed in Fig. S1-S3, $\dagger$ remarkably, receptor $\mathrm{L} 1$ can detect $\mathrm{F}^{-}$ion at a low concentration of $100 \mu \mathrm{M}$ with clearly colour development from colourless to light yellow. However, it should be mentioned that receptors L2 and L3 fail to sense fluoride in the same concentration, which was depicted in Fig. S2 and S3. $\uparrow$ By contrast, hydroxide anion cannot be sensed by receptors L1-L3 at the same concentration of $100 \mathrm{uM}$, as showed in Fig. S4-S6. $\dagger$

\section{UV-Vis spectral studies}

In order to understand the selective nature of the receptors towards fluoride and hydroxide anions, the sensing ability of receptors L1-L4 toward various anions $\left(\mathrm{Cl}^{-}, \mathrm{Br}^{-}, \mathrm{I}^{-}, \mathrm{H}_{2} \mathrm{PO}_{4}{ }^{-}\right.$, $\mathrm{HSO}_{4}{ }^{-}, \mathrm{CH}_{3} \mathrm{COO}^{-}, \mathrm{NO}_{3}{ }^{-}, \mathrm{ClO}_{4}{ }^{-}, \mathrm{OH}^{-}$and $\mathrm{ReO}_{4}{ }^{-}$) was further investigated by UV-Vis study. The UV-Vis experiments were performed in DMSO solution. The receptor solution $\left(5 \times 10^{-5}\right.$ M) was treated with 10 equivalents of each anion. As showed in Fig. S7-S10, $\dagger$ no bathochromic shift of other anions was observed for L1-L4, which is in line with the naked-eye

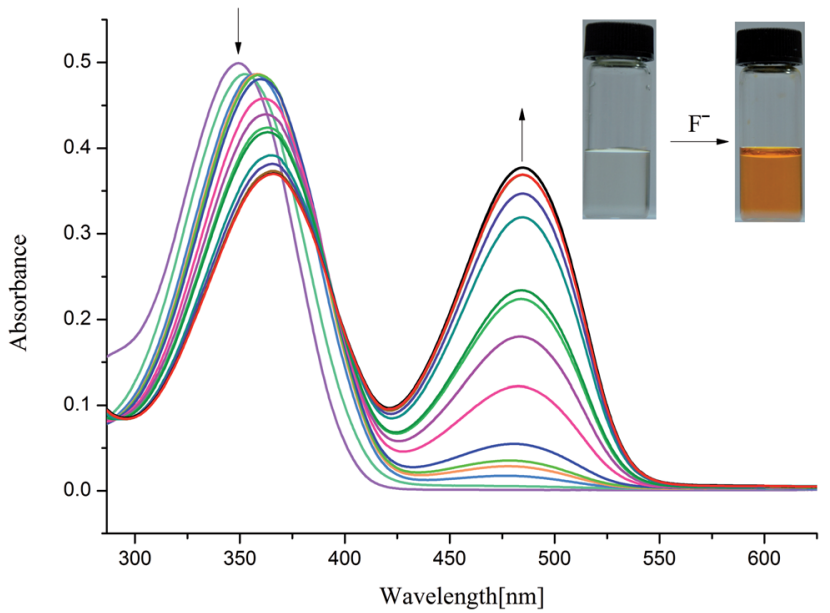

Fig. 2 Changes in UV-Vis spectra for L1 with addition of TBAF in DMSO solution ([L1] $=1.0 \times 10^{-5} \mathrm{M}$ ).

detection. However, a new peak appears in an infrared region in the course of titration of fluoride anion for L1-L3 except L4, as depicted in Fig. 2 and 3 and Fig. S11 and S12, $\uparrow$ which are also correlated with noticeable colour detection that $\mathrm{L} 4$ represents no discernible colour changes in the presence of excess fluoride anions. Specifically, the absorption spectra of L1 in DMSO solution $\left(1 \times 10^{-5} \mathrm{M}\right)$ displayed an intense absorption band at about $350 \mathrm{~nm}$ (Fig. 2), attributed to the $\pi-\pi^{*}$ transition of the $p$ nitrophenyl chromophore. Upon addition of incremental amounts of $\mathrm{F}^{-}$ions, the band at $350 \mathrm{~nm}$ progressively decreased, while a new peak at about $484 \mathrm{~nm}$ appeared and the intensity increased gradually (Fig. 2). This phenomenon might be ascribed to the $\mathrm{F}^{-}$-triggered urea complexation which extended the conjugated structure of the whole receptor. ${ }^{\mathbf{1 4 , 1 5}}$ Firstly, on addition of small amounts of $\mathrm{F}^{-}$produced a marked red shift in the absorption of $350 \mathrm{~nm}$ to $366 \mathrm{~nm}$ owing to the formation of genuine $\mathrm{H}$-bond complex. We suggested that a first equilibrium is established (see eqn (1)), inducing the formation of the hydrogen bond complex $[\mathrm{L}-\mathrm{H} \cdots \mathrm{F}]^{-}$, to which the band at $366 \mathrm{~nm}$ corresponds.

$$
[\mathrm{L}-\mathrm{H}]+\mathrm{F}^{-} \leftrightarrows[\mathrm{L}-\mathrm{H} \cdots \mathrm{F}]^{-}
$$

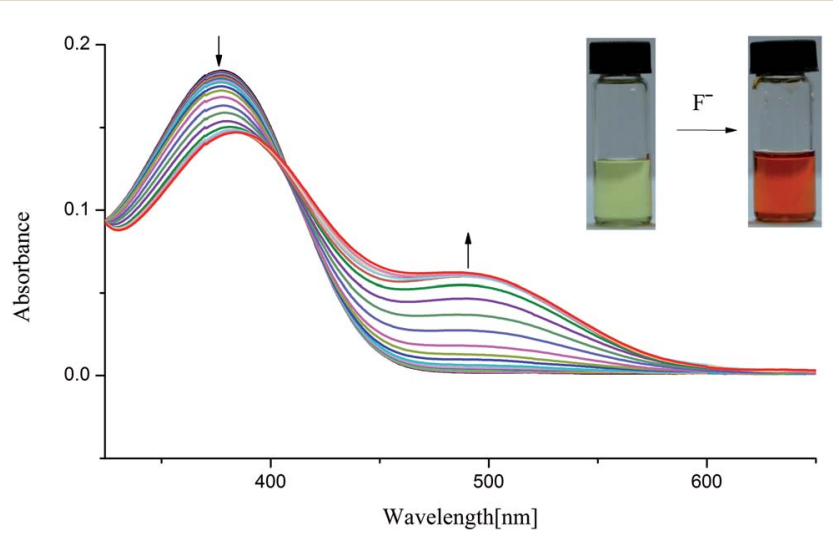

Fig. 3 Changes in UV-Vis spectra for L2 with addition of TBAF in DMSO solution ([L2] $\left.=1.0 \times 10^{-5} \mathrm{M}\right)$. 


$$
[\mathrm{L}-\mathrm{H} \cdots \mathrm{F}]+\mathrm{F}^{-} \leftrightarrows \mathrm{L}^{-}+\left[\mathrm{HF}_{2}\right]^{-}
$$

Then, on addition of more $\mathrm{F}^{-}$ions, a new band develops at $484 \mathrm{~nm}$, associate with the deprotonation of a proton from [L$\mathrm{H} \cdots \mathrm{F}]^{-}$producing an anionic receptor $\mathrm{L}^{-}$and $\mathrm{HF}_{2}{ }^{-}$(eqn (2)); ${ }^{14}$ these anions form only when more equivalents of fluoride anions were added. The deprotonation lowers the steric hindrance between the $\mathrm{NH}_{\mathrm{a}}$ or $\mathrm{NH}_{\mathrm{c}}$ groups and the nitrophenyl units, and therefore makes it possible to the formation of a $\pi$ conjugated plane with more extended areas. As a result, naked eye changes in colours from pale yellow to orange were found in the presence of excess fluoride anions. This deprotonation process had already been evidenced previously. For example, Fabbrizzi et al. stated that the $\mathrm{F}^{-}$ions first establishes a hydrogen-bonding interaction with urea receptors to give a stable 1:1 complex, and then on addition of a second equivalent, induces urea deprotonation, due to the formation of $\mathrm{HF}_{2}{ }^{-} \cdot{ }^{14,15}$ In another case, similar to L1, in the presence of saturated $\mathrm{F}^{-}$ions, a series of tripodal tris-urea based on mesitylene showed a similar bathochromic shifts with a decrease in its max absorbance and with a simultaneous increase in a higher absorption wavelength, corresponding to the deprotonation of these receptors. ${ }^{56}$

On the other hand, as mentioned above, upon addition of $\mathrm{F}^{-}$ ions the absorption of $\mathrm{L} 2$ at $377 \mathrm{~nm}$ progressively decreases and slightly red shift to $385 \mathrm{~nm}$, whereas the development of a new peak at $495 \mathrm{~nm}$ corresponds to anionic receptor is observed (Fig. 3). This new peak appeared for L2 in the presence of fluoride is red-shifted by $118 \mathrm{~nm}$, which is slightly smaller than that for L1 $(134 \mathrm{~nm})$, as showed in Fig. 2 and 3. In contrast, as depicted in Fig. S11, $\uparrow$ two very weak broad absorptions approximately at $467 \mathrm{~nm}$ and $423 \mathrm{~nm}$ were presented, when excess amount of $\mathrm{F}^{-}$was titrated with receptor $\mathrm{L} 3$. To verify the phenomenon of deprotonation, a titration of $\mathrm{L} 1$ with tetrabutylammonium hydroxide (TBAOH) was performed in the same conditions. Since TBAOH is a strong base, it is bound to induce the deprotonation of the receptor. On the addition of increasing amounts of TBAOH to the DMSO solution of L1 led to a sharp decrease of the band at $350 \mathrm{~nm}$ too, which is assigned to the $\pi$ $\pi^{*}$ transition of nitrophenyl chromophore; whereas, a new band centred at $490 \mathrm{~nm}$ appeared and increased gradually (Fig. S13 $\dagger$ ). Similar trend was observed for L2 with the absorption decrease at $377 \mathrm{~nm}$ and new bands development at 494 and $514 \mathrm{~nm}$ (Fig. S14†). In contrast, with respect to L3, the UV-Vis spectrum of $\mathrm{L} 3$ presented a slight difference absorption. The max absorption at $360 \mathrm{~nm}$ decreased simultaneously with one intense band developed at low wavelength of $297 \mathrm{~nm}$ and one broad band appeared around $497 \mathrm{~nm}$ (Fig. 4). A similar phenomenon was previously reported for $\mathrm{OH}^{-}$ions binding with a tripodal tris-urea receptor. The addition of more than 810 equivalents of TBAOH to mesitylene based tris-urea resulted in the emergence of a band at $474 \mathrm{~nm}(\Delta \lambda \sim 125 \mathrm{~nm}$, corresponding to deprotonation) with a simultaneous decrease in the absorption of the band at $348 \mathrm{~nm}$, and the latter disappearing completely after addition of 100 equivalents of the anions. ${ }^{56} \mathrm{An}$ in-depth interpretation of the interaction in the presence of $\mathrm{F}^{-}$

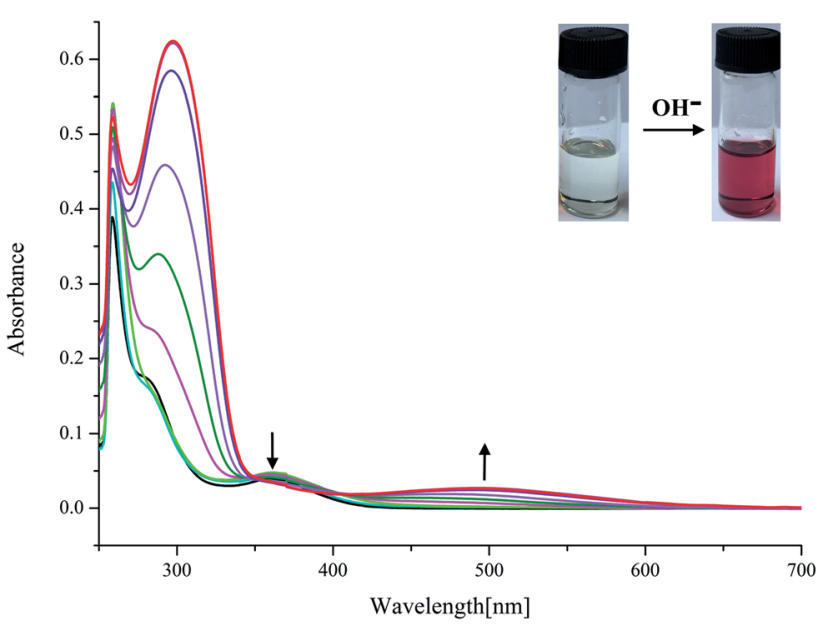

Fig. 4 Changes in UV-Vis spectra for $L 3$ with addition of TBAOH in DMSO solution ([L3] $\left.=1.0 \times 10^{-5} \mathrm{M}\right)$.

ions will be accomplished in conjunction with the results of the NMR experiments and theoretical calculations in the following sections.

\section{NMR titration studies}

As previous UV-Vis and the naked eye detection studies, we postulated the hydrogen bond formation and further deprotonation of the urea $\mathrm{N}-\mathrm{H}$ protons of receptors L1-L3 by excess fluoride and hydroxide anions cause the unique absorption behaviour and visible changes in colour. Nevertheless, it remains questionable how many protons had been deprotonated and in which order. To figure out these questions, L1 as a represented receptor and its NMR titration studies were pursued in further, while the titration profiles towards fluoride for receptors L2-L4 were also provided in Fig. S31-S33. $\dagger$ Here, the partial ${ }^{1} \mathrm{H}$ NMR spectra has been described in Fig. 5 and 6, the DMSO- $d_{6}$ solution of L1 $\left(5.0 \times 10^{-3} \mathrm{M}\right)$ was dealt with TBAF. Firstly, as posted in Fig. 5, upon addition of fluoride anions at low concentration, the ureido $\mathrm{N}-\mathrm{H}_{\mathrm{a}}(9.44 \mathrm{ppm}), \mathrm{N}-\mathrm{H}_{\mathrm{c}}(9.24$ ppm) and $\mathrm{N}-\mathrm{H}_{\mathrm{b}}(6.62 \mathrm{ppm})$ proton signals showed severe broadening with drastic downfield shift $(\Delta \delta=0.37,0.06$ and $0.76 \mathrm{ppm}$ ), this shift strongly indicates that fluoride binds to the ureido $\mathrm{N}-\mathrm{H}$ protons, forming a strong $\mathrm{H}$-bond with $\mathrm{N}-\mathrm{H}_{\mathrm{a}}, \mathrm{N}-\mathrm{H}_{\mathrm{c}}$ or $\mathrm{N}-\mathrm{H}_{\mathrm{b}}$ protons. This result is significantly coherent with the UV-Vis results that the equilibrium of eqn (1) is established. Specifically, on the addition of 0.15 equivalent of fluoride anions, the $\mathrm{N}-\mathrm{H}_{c}$ proton signal disappeared firstly. Subsequently, when 0.2 equivalent of TBAF was treated with the receptor, the $\mathrm{N}-\mathrm{H}_{\mathrm{a}}$ proton signal completely misses. In the next, the proton signal of $\mathrm{N}-\mathrm{H}_{\mathrm{b}}$, which is linked to an alkyl group, is the last one that disappeared from the NMR spectra, where 0.4 equivalent of $\mathrm{F}^{-}$ions was added. These results indicated that the fluoride ion preferably interacts with the ureido $\mathrm{N}-\mathrm{H}$ protons in the order of $\mathrm{N}-\mathrm{H}_{\mathrm{c}}>\mathrm{N}-\mathrm{H}_{\mathrm{a}}>\mathrm{N}-\mathrm{H}_{\mathrm{b}}$. Simultaneously, with the increasing amount of $\mathrm{F}^{-}$, the aromatic $\mathrm{C}-\mathrm{H}$ protons signals of $\mathrm{H}_{\mathrm{c} \alpha}, \mathrm{H}_{\mathrm{c} \beta}$ and $\mathrm{H}_{\mathrm{a} \alpha}$ exhibited a small up field shift due to the through-bond effects, which is because of the complexation of $\mathrm{L}-\mathrm{H} \cdots \mathrm{F}^{-}$and thus results in the increase of electron 


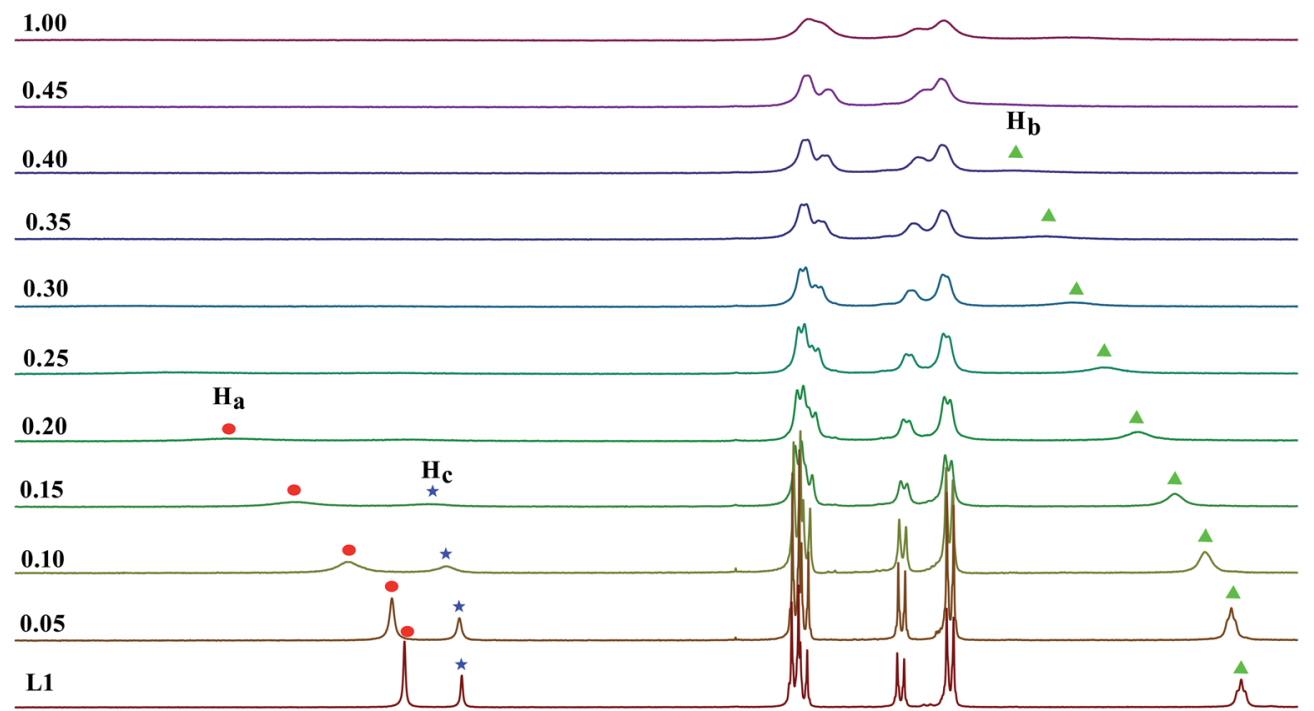

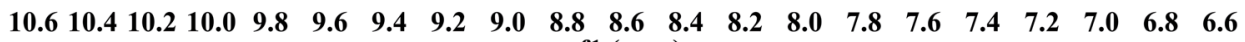
f1 (ppm)

Fig. 5 Stack plot of the ${ }^{1} \mathrm{H}$ NMR spectra of receptor L1 in the presence of increasing amounts of TBAF $\left(0-1\right.$ equiv.) recorded in DMSO- $d_{6}$ solution.

density. Whereas the $\mathrm{H}_{\mathrm{a} \beta}$ proton belongs to a dominant electrostatic effect that induces deshielding and causes a downfield shift, derived from a through-space effect.

Moreover, when more amounts of fluoride were treated with the receptor, a remarkably upfield shift of the $\mathrm{H}_{\mathrm{c} \alpha}$ and $\mathrm{H}_{\mathrm{c} \beta}$ protons as a result of increase through-bond charge delocalization is occurred, as is displayed in Fig. 6. This shift holds until the addition of 6.0 equivalents of $\mathrm{F}^{-}$ions. With further addition of excess $\mathrm{F}^{-}$ions, it has no effect on the $\mathrm{H}_{\mathrm{c} \alpha}$ and $\mathrm{H}_{\mathrm{c} \beta}$ protons, which is presumably because of the electron density increases through the more extended $\pi$-conjugated system due to the $\mathrm{N}-\mathrm{H}_{\mathrm{c}}$ proton completely leave the receptor molecule. In contrast, the $\mathrm{H}_{\mathrm{a} \alpha}$ and $\mathrm{H}_{\mathrm{a} \beta}$ protons almost stay constant up to the addition of 5.0 equivalents of fluoride anions. Then, these aromatic protons, which are linked with $-\mathrm{NH}_{\mathrm{a}}$ group, gradually undergo an upfield shift. This phenomenon is probably

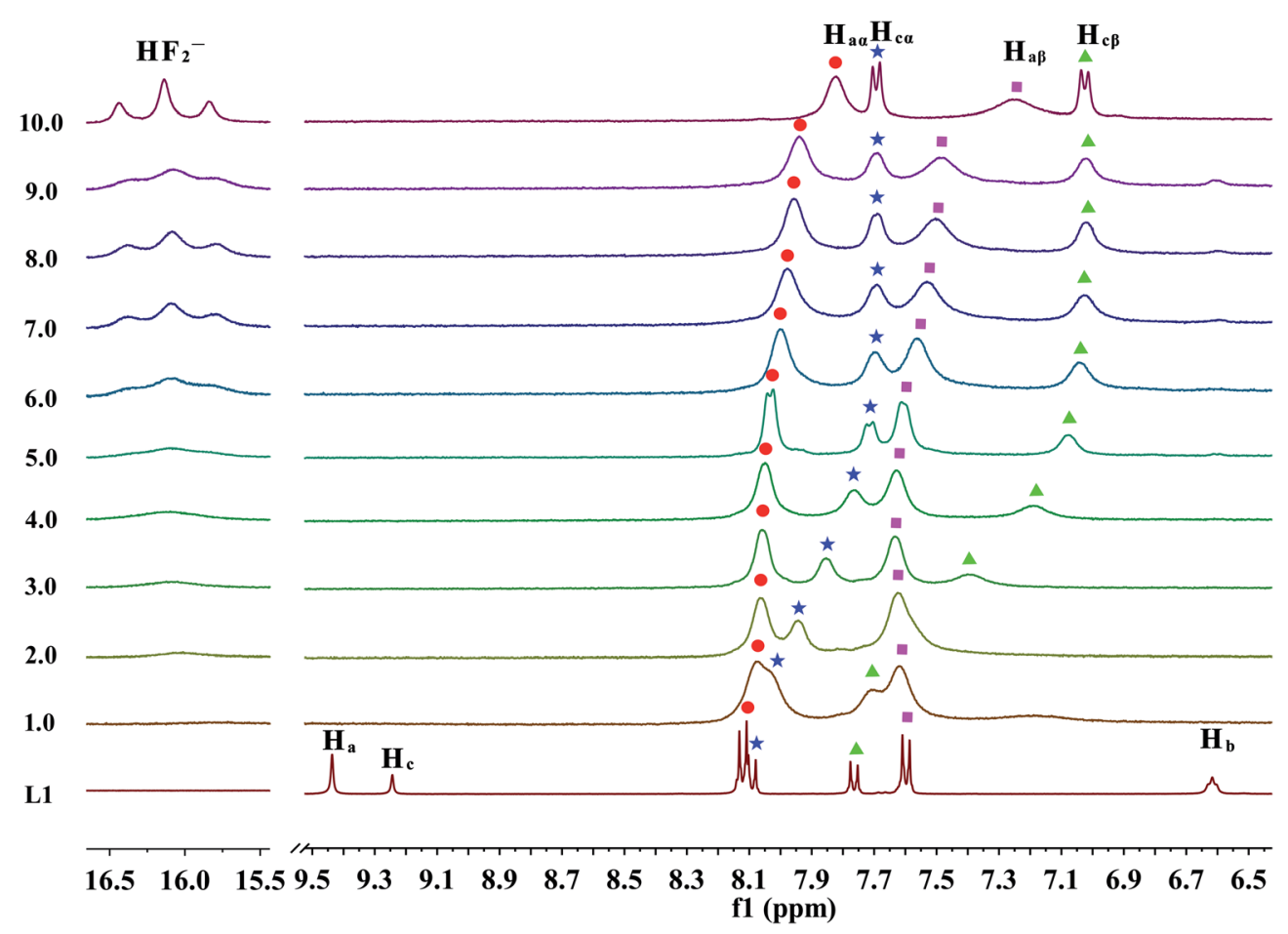

Fig. 6 Stack plot of the ${ }^{1} \mathrm{H}$ NMR spectra of receptor L1 in the presence of increasing amounts of TBAF (1-10 equiv.) recorded in DMSO- $d_{6}$. 
induced by a further deprotonation of $\mathrm{H}_{\mathrm{a}}$ or $\mathrm{H}_{\mathrm{a}^{\prime}}$ via a throughbond effect, increasing charge density of the ring connected with ureido $-\mathrm{NH}_{\mathrm{a}}$ or $-\mathrm{NH}_{\mathrm{a}^{\prime}}$ moiety, respectively. Overall, these results suggested that the deprotonation of $\mathrm{H}_{\mathrm{c}}$ proton prefers to $\mathrm{H}_{\mathrm{a}}$ or $\mathrm{H}_{\mathrm{a}^{\prime}}$ protons. Meanwhile, the urea deprotonation could be further evidenced by the occurrence of $\mathrm{HF}_{2}{ }^{-}$proton signals in the downfield of NMR spectrum. In particular, when 2.0 equivalents of fluoride anions was titrated into the solution of receptor L1, a broad proton signal around 16 ppm appears and increases gradually, which can be ascribed to the bi-fluoride anion $\left(\mathrm{FHF}^{-}\right)$, the most-stable hydrogen bond complex that fluoride ion can form, as is depicted in Fig. $6 .{ }^{15}$ However, in many cases, the strong hydrogen bonding also leads to the disappearance of the ureido proton signals which looks like to be the case here, while the UV-Vis titrations have indicated hydrogen bonding and not deprotonation in the case of their urea receptors. ${ }^{20,57}$ Although fluoride anion is not a specially strong base ( $\mathrm{p} K_{\mathrm{a}}=15$ in DMSO), ${ }^{58}$ however, the extreme stability of $\left[\mathrm{HF}_{2}\right]^{-}$anion is well indentified ${ }^{\mathbf{1 0 , 5 9}}$ and it is known to act as a very strong base, second to $\mathrm{OH}^{-}$in DMSO.

With respect to $\mathrm{OH}^{-}$, the addition of one equivalent of $\mathrm{OH}^{-}$ to the DMSO solution of receptors L1-L3 with EWG resulted in the complete disappearance of proton signals for all of the ureido $\mathrm{N}-\mathrm{H}$ protons $\left(\mathrm{N}-\mathrm{H}_{\mathrm{a}}, \mathrm{N}-\mathrm{H}_{\mathrm{b}}\right.$ and $\left.\mathrm{N}-\mathrm{H}_{\mathrm{c}}\right)$, which may signify their deprotonation too (Fig. S27-S29 $\dagger$ ). By contrast, the addition of $\mathrm{F}^{-}$to the solution of $\mathrm{L} 4$ led to the urea proton $\left(-\mathrm{H}_{\mathrm{a}},-\mathrm{H}_{\mathrm{b}}\right.$ and $-\mathrm{H}_{\mathrm{c}}$ ) signals broaden, whereas the more alkalinity hydroxide ion induced the urea proton signals disappeared completely (Fig. S30 $\dagger$ ). This is quite reasonable that although the $\mathrm{N}-\mathrm{H}$ acidity of $\mathrm{L} 4$ with EDG is weaker than that of L1-L3 with EWG, hydroxide is a stronger base in comparison with fluoride, which can induce the deprotonation of a weaker acid of urea $\mathrm{N}-\mathrm{H}$ in receptor $\mathrm{L} 4 .^{65}$

On the other hand, beside of the interaction between receptors and fluoride or hydroxide anions, we are also very curious about whether if other anions features binding affinity with receptors in the NMR time-scale. No obvious changes in NMR spectrum during the titration of one equivalent of each anion to receptors $\mathrm{L} 1-\mathrm{L} 4$ were observed $\left(\mathrm{Cl}^{-}, \mathrm{Br}^{-}, \mathrm{I}^{-}, \mathrm{NO}_{3}{ }^{-}\right.$, $\mathrm{ReO}_{4}{ }^{-}$and $\mathrm{ClO}_{4}{ }^{-}$), except $\mathrm{H}_{2} \mathrm{PO}_{4}{ }^{-}$and $\mathrm{CH}_{3} \mathrm{COO}^{-}$, as are set out in Fig. S27-S30. $\dagger$ Particularly, instead of strong broadening of the ureido $\mathrm{N}-\mathrm{H}$ proton signals in the presence of low concentration of $\mathrm{F}^{-}$ions, all of the three $\mathrm{N}-\mathrm{H}$ protons signals shifted to far downfield, corresponding to $\mathrm{N}-\mathrm{H}_{a}, \mathrm{~N}-\mathrm{H}_{\mathrm{c}}$ and $\mathrm{N}-\mathrm{H}_{\mathrm{b}}$ when one equivalent of $\mathrm{H}_{2} \mathrm{PO}_{4}{ }^{-}$was treated. In the case of $\mathrm{CH}_{3} \mathrm{COO}^{-}$, these protons signals show a similar behaves. Overall, these results suggested the formation of an interactive complex of tris-urea receptors with these two anions during the NMR titration. Furthermore, it should be pointed out that although the addition of $\mathrm{H}_{2} \mathrm{PO}_{4}{ }^{-}$and $\mathrm{CH}_{3} \mathrm{COO}^{-}$ions induced receptoranion interaction in NMR scale, however, no visible colour changes were observed during the NMR experiments, which may suggest no deprotonation in the presence of these two anions.

To aid discussion of anion binding capability, the $\mathrm{H}_{2} \mathrm{PO}_{4}{ }^{-}$ and $\mathrm{CH}_{3} \mathrm{COO}^{-}$binding constants for $\mathrm{L} 1-\mathrm{L} 4$ were determined by NMR titration (Fig. S34-S41†). Association constants of $\mathrm{F}^{-}$and
$\mathrm{OH}^{-}$anions could not be determined due to the deprotonation of the receptors in DMSO. When the data obtained upon stepwise anion addition were fitted to a $1: 1,2: 1$ and $1: 2$ binding models using BindFit software ${ }^{\mathbf{6}}{ }^{6}$ and the calculated association constants are summarised in Table $\mathrm{S} 1 . \dagger$ For $\mathrm{H}_{2} \mathrm{PO}_{4}{ }^{-}$, the binding data were best fit to a $1: 1$ binding model. In contrast, for $\mathrm{CH}_{3} \mathrm{COO}^{-}$, the titration data of $\mathrm{L} 3$ and $\mathrm{L} 4$ were best fit to a $2: 1$ binding model. This is presumably that the volume of $\mathrm{H}_{2} \mathrm{PO}_{4}{ }^{-}$is larger than that of $\mathrm{CH}_{3} \mathrm{COO}^{-}$leads to a better cooperative encapsulation by the two symmetric urea units $(\mathrm{N}-$ $\mathrm{H}_{\mathrm{a}}, \mathrm{N}-\mathrm{H}_{\mathrm{b}}, \mathrm{N}-\mathrm{H}_{\mathrm{a}^{\prime}}$ and $\left.\mathrm{N}-\mathrm{H}_{\mathrm{b}^{\prime}}\right)$ in one receptor; whereas the small volume of $\mathrm{CH}_{3} \mathrm{COO}^{-}$prefers to being capsuled by two urea unit from two different receptors. It needs to be noted that, in the case of $\mathrm{CH}_{3} \mathrm{COO}^{-}$, binding to the receptor L3 with meta EWG substituents was found to be stronger than those of other receptors $\left(\log K_{\mathrm{a}, 1: 1}=3.14, \log K_{\mathrm{a}, 2: 1}=3.11\right)$ (Table $\mathrm{S} 1 \dagger$ ). Unexpectedly, aryl substituents with EWG $\left(-\mathrm{NO}_{2}\right)$ for L1-L3 $\left(\log K_{\mathrm{a}, 1: 1}=1.90-2.44\right)$ resulted in a decrease in affinity for $\mathrm{H}_{2} \mathrm{PO}_{4}{ }^{-}$in comparison to that observed for phenyl derivative with EDG $\left(-\mathrm{CH}_{3}\right)$ for $\mathrm{L} 4\left(\log K_{\mathrm{a}, 1: 1}=2.52\right)$. This trend is slightly difference that normally observed for urea derivatives, where it is well-established that addition of aryl substituents bearing EWG increases affinity for a range of anions. ${ }^{67}$

\section{X-ray crystal structure analysis}

The role of hydrogen bonding in assembling receptor and anion complex species in the solid state is visualized by crystal packing. Regardless of the fact that crystallizations of the receptors and their anion complexes were carried out, however, the difficulties in crystallization of complex species limited our efforts directly figuring out the interaction of anions with receptors. Nevertheless, the crystal structures of some of the receptors, L1-L3, still can provide some helpful information. Firstly, yellowish single-crystal of $\mathrm{L} 1 \cdot 0.5\left(\mathrm{Et}_{2} \mathrm{O}\right)$ with rectangular shape was grown by slow evaporation of a DMF solution of the receptor with one equivalent of $\left[\mathrm{NH}_{4}\right]\left[\mathrm{ReO}_{4}\right]$ in three weeks. As showed in Fig. 7, one intramolecular hydrogen bond is found and the bond length $(\mathrm{H} 5 \cdots \mathrm{O} 7)$ for $\mathrm{N}-\mathrm{H} \cdots \mathrm{O}$ is $2.056 \AA$. Obviously, the distance in space between the other two urea motifs is really far from each other, forming this intramolecular hydrogen bond. Besides, it is worth noting that two carbon atoms (C17 and C18) and one nitrogen atom (N7) between N4 and $\mathrm{C} 19$ are disordered in this structure due to the labile of the hydrocarbon chain in this molecule, as is represented in Fig. 7. Accordingly, these two urea motifs vibrates on the up and down sides of the amide plane (O4-C10-N4-C9), even so the two urea motifs in one receptor molecule look like hardly assemble into a cooperative conformation to encapsulate anions in one cavity. Meanwhile, single-crystal of free receptor L2 suitable for XRD determination was isolated by slow evaporation of a DMSO solution of $\mathrm{L} 2$ in a few weeks. This crystal is found in a yellowish colour with tabular shape. As showed in Fig. 8, there are three $\mathrm{N}-\mathrm{H} \cdots \mathrm{O}$ intramolecular hydrogen bonds in the range of 1.975$2.116 \AA$ between one oxygen of a nitro group and the nearest hydrogen of $\mathrm{N}-\mathrm{H}_{\mathrm{a}}$ or $\mathrm{N}-\mathrm{H}_{\mathrm{a}^{\prime}}$ in each urea motif. In comparison with L1, the two urea motifs, which are connected with a labile 


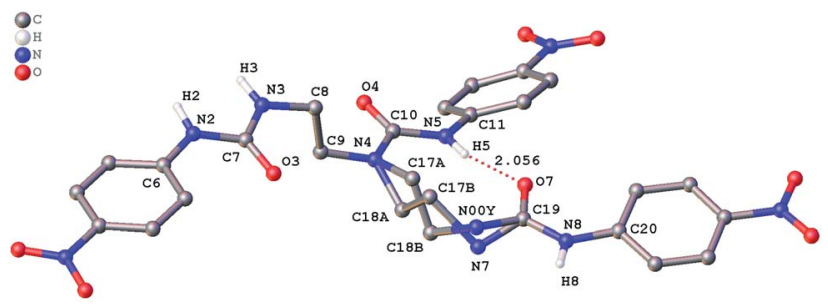

Fig. 7 Crystal structure of $\mathrm{L} 1 \cdot 0.5\left(\mathrm{Et}_{2} \mathrm{O}\right)$ with ellipsoids shown at the $25 \%$ probability level. Hydrogen atoms attached to carbons and the diethyl ether molecule have been omitted for clarity.

carbon chain, are on the opposite side of the O4-C10-N4-C9 amide plane in L2. In addition, rectangular crystals of L3 DMSO were grown by slow evaporation of a DMSO solution of receptor $\mathrm{L} 3$ with one equivalent $[\mathrm{TBA}]\left[\mathrm{HSO}_{4}\right]$ in one month. One $\mathrm{N}-\mathrm{H} \cdots \mathrm{O}$ intramolecular hydrogen bond length is of $2.095 \AA$ ( $\mathrm{N} 8-\mathrm{H} 8 \cdots$ O3), as is shown in Fig. 9. Interestingly, one DMSO molecule is co-crystalized with L3 and hydrogen bonded to H6 in one of urea motifs. This intermolecular hydrogen bond length is 1.915

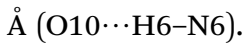

On the other hand, it also needs to be mentioned that we attempted to obtain crystal structures of the deprotonated receptors for further evidencing the above experimental observation that tris-urea receptors can be deprotonated by excess of $\mathrm{F}^{-}$ions. During the course of the above titration experiments, we observed that upon leaving the coloured solutions of receptors with TBAF open to the air for several hours, the colour change reversed. We firstly speculated this to be resulted from the absorption of water from the atmosphere. To investigate this further, we attempted to grow crystals from the solution of receptors with excess of TBAF (or the deprotonated form of $\mathrm{L}$ after addition of $\mathrm{F}^{-}$) under a dry atmosphere. Unfortunately, although crystals of receptors with TBAF were isolated, these crystals were not suitable for single-crystal diffraction determination. Nevertheless, crystals suitable for single-crystal XRD experiment were obtained by diethyl ether vapour-diffusion into an acetone solution of L1 and TBAF in a closed container. The obtained structure displayed that these crystals are not the deprotonated form of L1. However, in fact it is the TBA salt of $\mathrm{HCO}_{3}{ }^{-}$ion, this bicarbonate anion presumably was produced from atmospheric $\mathrm{CO}_{2}$, which was fixed by the basic TBAF solution. This phenomenon is also reported previously. Specifically, a 1,3-bis(4-nitrophenyl)urea receptor, the addition

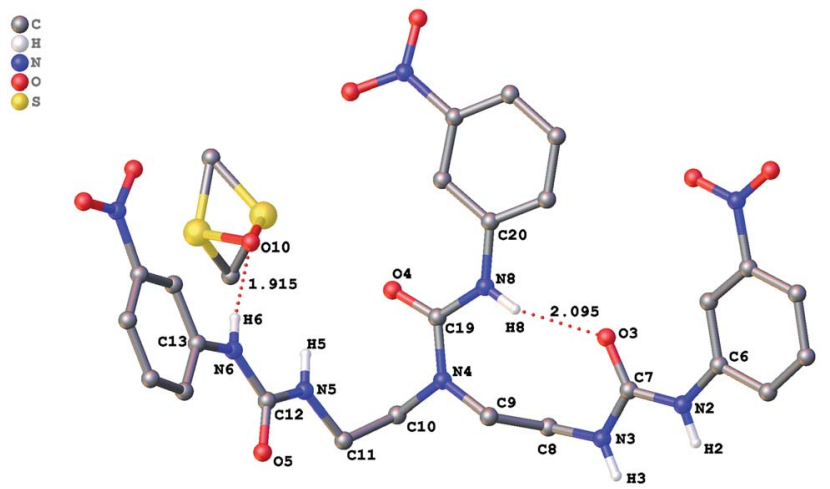

Fig. 9 Crystal structure of L3.DMSO with ellipsoids shown at the $25 \%$ probability level. Hydrogen atoms attached to carbons have been omitted for clarity.

of excess $\mathrm{F}^{-}$induced the deprotonation of the urea N-H group, and that following fixation of atmospheric $\mathrm{CO}_{2}$, an $\mathrm{H}$-bond complex formed between the neutral receptor and $\mathrm{HCO}_{3}{ }^{-}{ }^{14}$ In another case, a tren-based tris-urea receptor with EWGs can efficiently capture and fix atmospheric $\mathrm{CO}_{2}$ as air-stable crystals of a $\mathrm{CO}_{3}{ }^{2-}$-encapsulated molecular capsule, triggered by the presence of TBAF/TBAOH in a DMSO solution of receptor. ${ }^{36}$

\section{Theoretical studies}

In order to acquire insight on the receptors and the corresponding anionic receptors at the molecular level, we carried out theoretical studies using the density functional theory employing Gaussian 09 program. The previous studies have indicated that the M06-2X functional provides a satisfactory description of non-covalent interactions in comparison with other density functionals. ${ }^{60-63}$ The above titrations results suggest that the interaction between receptors and fluoride anion undergoes a multi-step reaction: hydrogen bond formation and stepwise deprotonation of urea protons. However, the detailed deprotonation process is still unclear. Thus, DFT studies related to this deprotonation process were carried out and the following kinetic eqn (3)-(7) established based on experimental results had been systematically investigated:

$$
\begin{gathered}
{\left[\mathrm{L}-\mathrm{H}_{5}\right]+2 \mathrm{~F}^{-} \leftrightarrows\left[\mathrm{L}-\mathrm{H}_{4}\right]^{-}+\left[\mathrm{HF}_{2}\right]^{-}} \\
{\left[\mathrm{L}-\mathrm{H}_{4}\right]^{-}+2 \mathrm{~F}^{-} \leftrightarrows\left[\mathrm{L}-\mathrm{H}_{3}\right]^{2-}+\left[\mathrm{HF}_{2}\right]^{-}}
\end{gathered}
$$
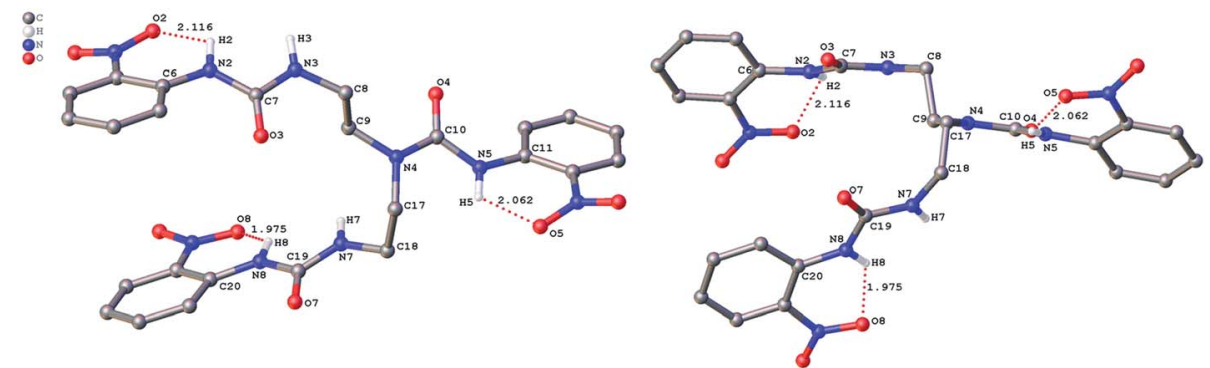

Fig. 8 Crystal structure of L2 (left, top view; right, side view) with ellipsoids shown at the $25 \%$ probability level. Hydrogen atoms attached to carbons have been omitted for clarity. 
Table 1 The stepwise deprotonation energies $\left(E_{\mathrm{d}}\right.$, $\left.\mathrm{kcal} \mathrm{mol}^{-1}\right)$ of $L 1$ for $\mathrm{N}-\mathrm{H}_{\mathrm{c}}, \mathrm{N}-\mathrm{H}_{\mathrm{a}}, \mathrm{N}-\mathrm{H}_{\mathrm{a}^{\prime}}, \mathrm{N}-\mathrm{H}_{\mathrm{b}}$ and $\mathrm{N}-\mathrm{H}_{\mathrm{b}^{\prime}}$ according to eqn (3)-(7) by M06-2X/6-311+G(d,p)//6-311G(d,p) with PCM model ${ }^{a}$

\begin{tabular}{llllll}
\hline L1 & Eqn (3) & Eqn (4) & Eqn (5) & Eqn (6) & Eqn (7) \\
\hline$E_{\mathrm{d}}$ & -19.87 & -23.27 & -23.10 & 1.05 & 1.99 \\
${ }^{a}$ Calculated in DMSO solution. & & &
\end{tabular}

$$
\begin{gathered}
{\left[\mathrm{L}-\mathrm{H}_{3}\right]^{2-}+2 \mathrm{~F}^{-} \leftrightarrows\left[\mathrm{L}-\mathrm{H}_{2}\right]^{3-}+\left[\mathrm{HF}_{2}\right]^{-}} \\
{\left[\mathrm{L}-\mathrm{H}_{2}\right]^{3-}+2 \mathrm{~F}^{-} \leftrightarrows[\mathrm{L}-\mathrm{H}]^{4-}+\left[\mathrm{HF}_{2}\right]^{-}} \\
{[\mathrm{L}-\mathrm{H}]^{4-}+2 \mathrm{~F}^{-} \leftrightarrows \mathrm{L}^{5-}+\left[\mathrm{HF}_{2}\right]^{-}}
\end{gathered}
$$

The stepwise deprotonation energies of L1 were summarized in Table 1. The deprotonation energy was calculated according to $E_{\mathrm{d}}=E\left([\mathrm{~L}]^{-}\right)+E\left(\mathrm{HF}_{2}^{-}\right)-E(\mathrm{~L})-2 E\left(\mathrm{~F}^{-}\right)$. Particularly, with the NMR experiments, the $\mathrm{N}-\mathrm{H}_{\mathrm{c}}$ proton disappeared first in comparison with other two protons, $\mathrm{N}-\mathrm{H}_{\mathrm{a}}$ and $\mathrm{N}-\mathrm{H}_{\mathrm{b}}$. In addition, signals of aromatic $\mathrm{C}-\mathrm{H}$ linked to $\mathrm{N}-\mathrm{H}_{\mathrm{c}}$ were drastically moved to upfield with the development of $\mathrm{HF}_{2}{ }^{-}$ion. These results proved the $\mathrm{N}-\mathrm{H}_{\mathrm{c}}$ proton deprotonated first over other $\mathrm{N}-\mathrm{H}$ protons in this receptor molecule. Our findings are in accordance well with DFT calculations that the deprotonation energy of $\mathrm{N}-\mathrm{H}_{\mathrm{c}}$ by $\mathrm{F}^{-}$for $\mathrm{L} 1$ is $-19.87 \mathrm{kcal} \mathrm{mol}^{-1}$ according to eqn (3), as is shown in Table 1. Obviously, the second deprotonation of ureido proton by $\mathrm{F}^{-}$ion has two options, two $\mathrm{N}-\mathrm{H}_{\mathrm{a}}$ $\left(\mathrm{N}-\mathrm{H}_{\mathrm{a}^{\prime}}\right)$ or two $\mathrm{N}-\mathrm{H}_{\mathrm{b}}\left(\mathrm{N}-\mathrm{H}_{\mathrm{b}^{\prime}}\right)$. Unsurprisingly, deprotonation energy for $\mathrm{N}-\mathrm{H}_{\mathrm{a}}$ is around $-23 \mathrm{kcal} \mathrm{mol}^{-1}$ according to eqn (4), which is about $7.5 \mathrm{kcal} \mathrm{mol}^{-1}$ lower than that for $\mathrm{N}-\mathrm{H}_{\mathrm{b}}$ (Fig. S42†). This lower deprotonation energy of $\mathrm{N}-\mathrm{H}_{\mathrm{a}}$ compared with $\mathrm{N}-\mathrm{H}_{\mathrm{b}}$ is probably because that the $\mathrm{N}-\mathrm{H}_{\mathrm{b}}$ is linked with a methylene group whereas the $\mathrm{N}-\mathrm{H}_{\mathrm{a}}$ is connected to an aromatic ring. It is quite reasonable that the nitrophenyl ring can stabilize the negative charge from the deprotonated ureido $\mathrm{N}$ atom preferring to the alkyl carbon. This phenomenon was further evidenced by the deprotonation of $\mathrm{N}-\mathrm{H}_{\mathrm{b}}$ or $\mathrm{N}-\mathrm{H}_{\mathrm{b}^{\prime}}$, which is energetic unfavourable by 1.05 and $1.99 \mathrm{kcal} \mathrm{mol}^{-1}$ higher for $\mathrm{N}-\mathrm{H}_{\mathrm{a}}$ and $\mathrm{N}-\mathrm{H}_{\mathrm{a}^{\prime}}$ according to eqn (6) and (7), respectively, as is provided in Table 1 . This result also implied that the $\mathrm{N}-\mathrm{H}_{\mathrm{b}}$ bond is unfavourable to be dissociation by fluoride anions in DMSO solution. Overall, the deprotonations of these three ureido protons, one $\mathrm{N}-\mathrm{H}_{\mathrm{c}}$ and two $\mathrm{N}-\mathrm{H}_{\mathrm{a}}$ (or $\mathrm{N}-\mathrm{H}_{\mathrm{a}^{\prime}}$ ), prefers to those two ureido $\mathrm{N}-\mathrm{H}_{\mathrm{b}}\left(\right.$ or $\left.\mathrm{N}-\mathrm{H}_{\mathrm{b}^{\prime}}\right)$ protons. This result matches well with the above experimental studies. This deprotonation behaviour of urea receptors by fluoride or hydroxide anions had been evidenced experimentally in previous. ${ }^{14,15,56}$

On the other hand, in order to compare the deprotonation abilities for all of the receptors, we also performed the DFT calculations on deprotonation energies of the three protons as $E_{\mathrm{d} 3}=E\left(\left[\mathrm{~L}-\mathrm{H}_{2}\right]^{3-}\right)+E\left(\mathrm{HF}_{2}^{-}\right)-E\left(\left[\mathrm{~L}-\mathrm{H}_{3}\right]^{2-}\right)-2 E\left(\mathrm{~F}^{-}\right)$, one N- $\mathrm{H}_{\mathrm{c}}$ and two $\mathrm{N}-\mathrm{H}_{\mathrm{a}}$ (or $\mathrm{N}-\mathrm{H}_{\mathrm{a}^{\prime}}$, for L1-L4 with a combination of eqn (3)-(5). The tendency of deprotonation for receptors affording trianion was in the order of $\mathrm{L}^{3-}>\mathrm{L}^{3-}>\mathrm{L}^{3-}>\mathrm{L} 4^{3-}$. And these deprotonation energies were provided in Table S2. $\dagger$ This result is quite reasonable that EWG $\left(-\mathrm{NO}_{2}\right)$ on a phenyl ring increase the acidity of the ureido proton compared with the EDG $(-m-\mathrm{Me}$, L4), which is correlated with the previous study. ${ }^{64,65}$ It can be seen that the introduction of EWG on the para position increases the stability of the receptor trianion in comparison with that on the ortho or the meta positions.

To gain further insight on the colorimetric visible observation toward fluoride, electronic properties of neutral receptors and the corresponding receptors trianion were studied

\begin{tabular}{|c|c|c|c|c|c|}
\hline Receptors/anion & Excited state & Transition wavelength (nm) & $f$ & Configuration $^{a}$ & $\lambda_{\exp }(\mathrm{nm})$ \\
\hline L1 & 1 & 338 & 0.6097 & $\mathrm{H} \rightarrow \mathrm{L}+2(72 \%)$ & $350,484^{b}$ \\
\hline $\mathrm{L}^{3-}$ & 1 & 421 & 0.6350 & $\begin{array}{l}\mathrm{H} \rightarrow \mathrm{L}(55 \%) \\
\mathrm{H} \rightarrow \mathrm{L}+1(33 \%)\end{array}$ & \\
\hline $\mathrm{L} 2$ & $\begin{array}{l}1 \\
2\end{array}$ & $\begin{array}{l}393 \\
380\end{array}$ & $\begin{array}{l}0.0300 \\
0.1583\end{array}$ & $\begin{array}{l}\mathrm{H} \rightarrow \mathrm{L}(79 \%) \\
\mathrm{H}-1 \rightarrow \mathrm{L}+1(38 \%) \\
\mathrm{H} \rightarrow \mathrm{L}+1(52 \%)\end{array}$ & $377,495^{b}$ \\
\hline $\mathrm{L} 2^{3-}$ & $\begin{array}{l}1 \\
4\end{array}$ & $\begin{array}{l}491 \\
426\end{array}$ & $\begin{array}{l}0.1088 \\
0.1666\end{array}$ & $\begin{array}{l}\mathrm{H} \rightarrow \mathrm{L}(66 \%) \\
\mathrm{H}-2 \rightarrow \mathrm{L}+1(63 \%)\end{array}$ & \\
\hline L3 & $\begin{array}{l}1 \\
4\end{array}$ & $\begin{array}{l}388 \\
363\end{array}$ & $\begin{array}{l}0.0201 \\
0.0308\end{array}$ & $\begin{array}{l}\mathrm{H} \rightarrow \mathrm{L}+1(56 \%) \\
\mathrm{H} \rightarrow \mathrm{L}(53 \%)\end{array}$ & $356,421^{c}$ \\
\hline $\mathrm{L}^{3-}$ & $\begin{array}{l}1 \\
4\end{array}$ & $\begin{array}{l}598 \\
567\end{array}$ & $\begin{array}{l}0.0197 \\
0.0177\end{array}$ & $\begin{array}{l}\mathrm{H} \rightarrow \mathrm{L}+1(85 \%) \\
\mathrm{H}-2 \rightarrow \mathrm{L}(49 \%)\end{array}$ & \\
\hline $\mathrm{L} 4$ & $\begin{array}{l}1 \\
5\end{array}$ & $\begin{array}{l}254 \\
236\end{array}$ & $\begin{array}{l}0.0391 \\
0.4904\end{array}$ & $\begin{array}{l}\mathrm{H}-1 \rightarrow \mathrm{L}+1(55 \%) \\
\mathrm{H} \rightarrow \mathrm{L}+3(13 \%) \\
\mathrm{H} \rightarrow \mathrm{L}+4(26 \%)\end{array}$ & $275,376^{c}$ \\
\hline $\mathrm{L}^{3-}$ & $\begin{array}{l}1 \\
7\end{array}$ & $\begin{array}{l}301 \\
268\end{array}$ & $\begin{array}{l}0.0450 \\
0.7946\end{array}$ & $\begin{array}{l}\mathrm{H}-1 \rightarrow \mathrm{L}(60 \%) \\
\mathrm{H}-2 \rightarrow \mathrm{L}+4(18 \%) \\
\mathrm{H}-1 \rightarrow \mathrm{L}+4(16 \%) \\
\mathrm{H}-1 \rightarrow \mathrm{L}+5(27)\end{array}$ & \\
\hline
\end{tabular}

Table 2 The calculated absorption spectra, oscillator strengths $f$ and the assignment of $S_{0}$ to $S_{i}$ transitions for receptors and their deprotonated trianion using TDDFT at PBEO/def2-TZVP level in DMSO media, along with experimental UV-Vis absorption of maximum in DMSO solution

\footnotetext{
${ }^{a} \mathrm{H}$ denotes HOMO and L denotes LUMO. ${ }^{b}$ A sharp absorption band developed upon the titration of fluoride. ${ }^{c}$ A very weak absorption band
} developed upon the titration of fluoride. 
<smiles>CCC(=C(C)C)C(C)C(C)C(C)C(C)C(C)C1C(C)C(C)C(C(C)(C)C)C(C)C1C</smiles>

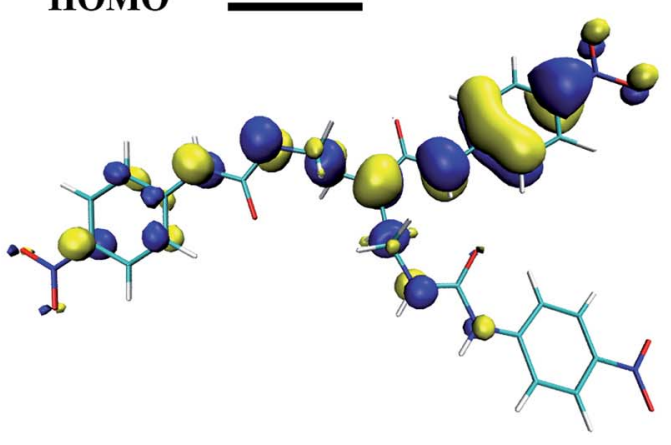

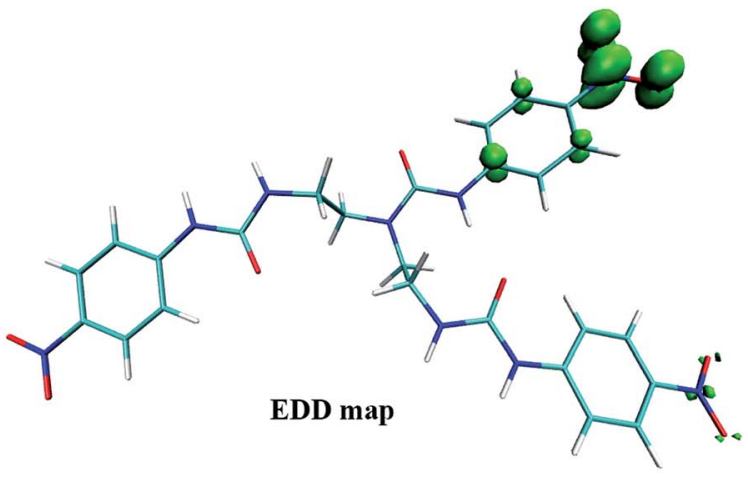
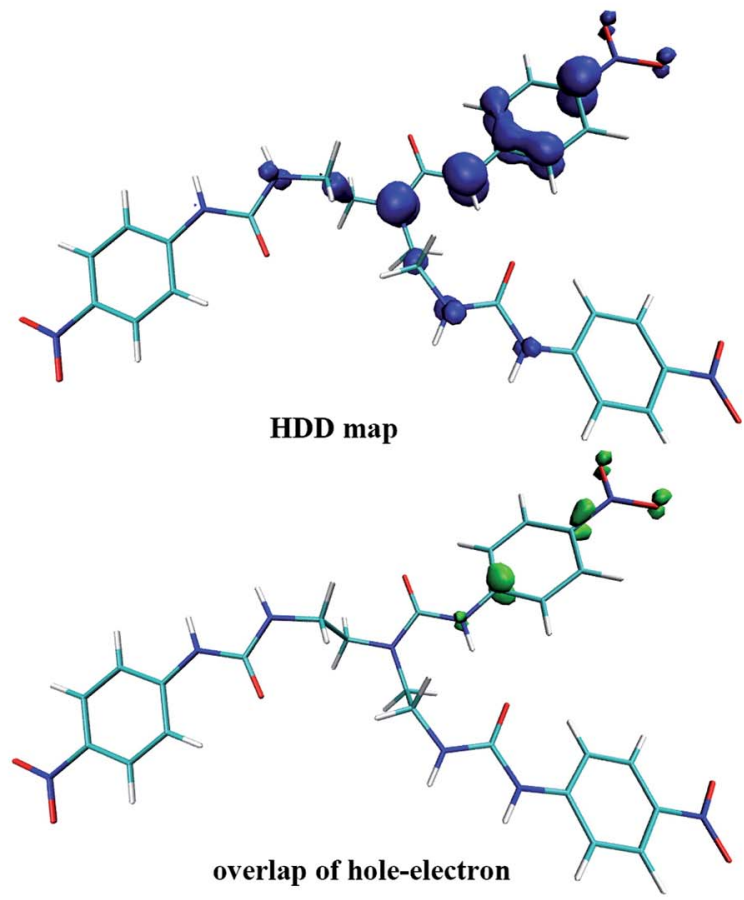

Fig. 10 Associated molecular orbitals, oscillator strength and main contribution of the $338 \mathrm{~nm}$ transition of receptor L1, calculated via TDDFTPBE0/def2-TZVP level with PCM in DMSO. Electron (EDD) and hole (HDD) density distribution maps associated with receptor L1 excited state corresponding to $338 \mathrm{~nm}$ electronic transition.

employing TDDFT method in PBE0/def2-TZVP level of theory using the geometry optimized above. For all the species, we have calculated the lowest 10 excited states in DMSO media with PCM model. Transition wavelengths, oscillator strengths and main contribution were summarized in Table 2. For receptors L1-L4, the calculated absorption is in reasonable agreement with the experimental results. In particular, the first absorption peak of L1 locates at $338 \mathrm{~nm}$ with an oscillator strength $f=$ 0.6097 , which is in agreement with the experimental wavelength of $350 \mathrm{~nm}$ (Fig. 2). This absorption is assigned to the HOMO $\rightarrow$ LUMO+2 $(72 \%)$ transition with obvious intramolecular charge transfer (ICT) character, as is depicted in Fig. 10. The deprotonation of $\mathrm{L} 1$ presumably generated $\mathrm{L}^{3-}$ in DMSO solution, which has been discussed above, causes a significant red shift from 338 to $421 \mathrm{~nm}$ (from 350 to $484 \mathrm{~nm}$ for experimental data) for the first absorption peak. This absorption of $\mathrm{L}^{3-}$ originated from HOMO $\rightarrow$ LUMO (55\%) and HOMO $\rightarrow$ LUMO+1 (33\%) transitions (Table 2, Fig. 11). In addition, since the deprotonation energy of the first two steps are quite low (Table 1), to figure out the contribution of these two anions to the absorption, we also performed TDDFT calculations for mono anion and dianion of $\mathrm{L} 1$. The corresponding TDDFT results for $\mathrm{L}^{-}$and $\mathrm{L}^{2-}$ were also provided in Table S3. $\dagger$ The first absorptions of $\mathrm{L}^{-}$ and $\mathrm{L}^{2-}$ are $400(\mathrm{~S} 3, f=0.8904)$ and $386 \mathrm{~nm}(\mathrm{~S} 6, f=0.7328)$, respectively, which are respectively ascribed to the HOMO $\rightarrow$ LUMO+2 (99\%) and HOMO-1 $\rightarrow$ LUMO+2 (61\%) transitions (Table S3 $\dagger$ ). Although these two absorptions are also both red shifted 62 and $48 \mathrm{~nm}$ with respect to that of L1, respectively, the experimental absorption is in better line with the calculated results of the deprotonated trianion $\mathrm{L}^{3-}$. These TDDFT results are in good agreement with the thermodynamic calculations.

Similarly, L2 represented a noticeable red shift absorption from $380(\mathrm{~S} 2, f=0.1583)$ to $491 \mathrm{~nm}(\mathrm{~S} 1, f=0.1088)$ due to the deprotonation of L2. This shift (111 nm) is in well agreement with the experimental spectrum from 377 to $495 \mathrm{~nm}(118 \mathrm{~nm})$ (Table 2). It is worth noting that although a red shift for $\mathrm{L} 3$ from 363 to $598 \mathrm{~nm}$ was found with TDDFT calculations, while the experimental spectrum in the lower energy region for L3 

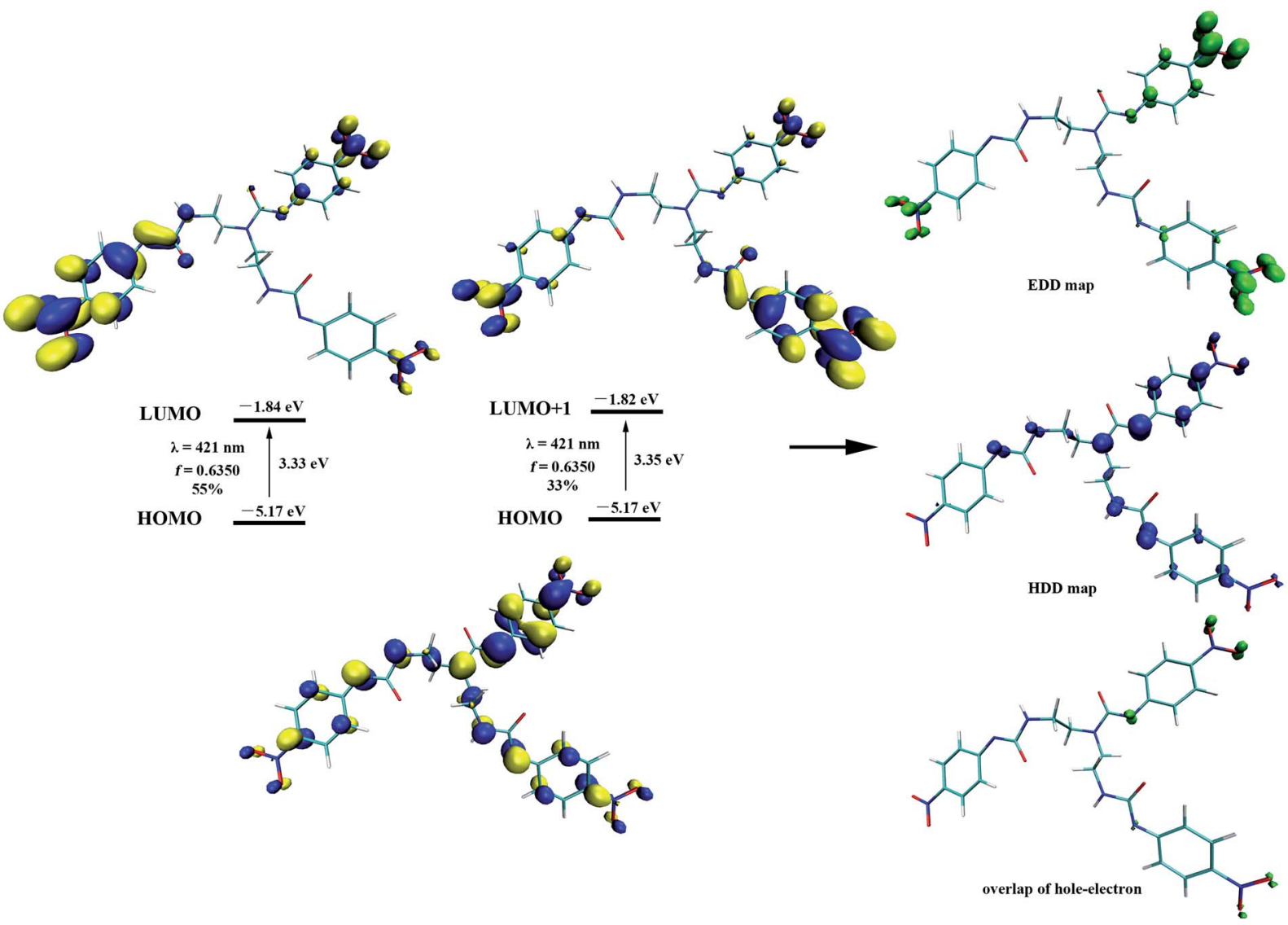

Fig. 11 Associated molecular orbitals, the oscillator strength and the main contribution of the $421 \mathrm{~nm}$ transition of receptor trianion $\mathrm{L} 1^{3-}$, calculated via TDDFT-PBE0/def2-TZVP level with PCM in DMSO. Electron (EDD) and hole (HDD) density distribution maps associated with receptor trianion $\mathrm{L}^{3-}$ excited state corresponding to $421 \mathrm{~nm}$ electronic transition.

displays weak absorption presumably due to the small oscillator strength values. The oscillator strength for $\mathrm{L}^{3-}$ are 0.0197 (S1) and 0.0177 (S4), which are much smaller than those for $\mathrm{L}^{3-}$ or $\mathrm{L}_{2}{ }^{3-}$. Nevertheless, this result correlated well with the UV-Vis experimental results.

In contrast to the result for EWG substituent, the EDG substituent significantly increased the excitation energy of the urea receptor in L4. This lead to a blue shift of the first absorption ( $\mathrm{S} 5,236 \mathrm{~nm}$ ) for $\mathrm{L} 4$ with an oscillator strength $f=$ 0.4904. It should be mentioned that even the calculated absorption peak for $\mathrm{L} 4$ has a slight deviation from the experimental value $(275 \mathrm{~nm})$, its excited transition could also give a reasonable result comparable with the experimental observation. In comparison with the absorption of $\mathrm{L} 4$, although the deprotonated trianion $\mathrm{L}^{3-}$ represents a small red shift $(32 \mathrm{~nm})$, as is presented in Table 2, its max absorption is also located in a UV region $(268 \mathrm{~nm})$ which cannot result in a visible change in colour on the addition of excess of $\mathrm{F}^{-}$to $\mathrm{L} 4$.

In light of the nonapplicability of a single molecular orbital pair excitation model, the issue was avoided by conceptualizing multi-molecular orbital excitations in accordance with electron (EDD) and hole (HDD) density distribution, providing very clear features of excited state for the receptors and the corresponding receptors anion. EDD (green) and HDD (blue) maps denoting the regions where an electron goes and leaves to be examined, respectively, as depicted in Fig. 10 and 11. Concerning the L1, the EDD region mainly located at the nitro group on the phenyl ring linked to $\mathrm{N}-\mathrm{H}_{\mathrm{c}}$, while the HDD spread through the urea $(\mathrm{N}-$ $\mathrm{H}_{\mathrm{c}}$ ) moiety, particularly on the nitrogen atoms and the connected three aromatic carbon. It can be seen that the overlap of EDD and HDD is very small (Fig. 10), this means the electron and hole are almost separated, indicating a typical intramolecular CT excited state. Thus, we decided to use Multiwfn program $^{52}$ again and calculate the $\Delta r$ coefficient which is useful when it comes to the identification of excitation type ${ }^{68}$ As stated by Guido et al., locally excited (LE) type are characterized by $\Delta r$ index smaller than 2.0 $\AA$. The higher the $\Delta r$ index is, the more likely is that the excitation is of CT mode. In the present case of L1, the $\Delta r$ index is $6.510 \AA$ (Table S4 $\dagger$ ), distinctly indicating a CT excitation mode. In addition, we further performed a calculation of distance between centroids of electrons and holes $(D)$, which is another measure of CT length and is an indicator of excitation type. The larger the value, the longer length the charge transfers. According to high $D$ value of $3.863 \AA$ for $\mathrm{L} 1$, we can finally point out that the excited mode of S1 belongs to CT type (Table S4 $\uparrow$ ). These results are in accordance with the main $\mathrm{MO}$ contribution from HOMO to LUMO+2, that the HOMO locates around the whole molecule while the LUMO+2 focuses on the phenyl ring linked to ureido $\mathrm{N}-\mathrm{H}_{\mathrm{c}}$ group, as is shown in Fig. 10. 
On the other hand, as can be seen that the HDD map for $\mathrm{L}^{3-}$ delocalizes over the whole molecule, including three urea moieties, $\mathrm{H}_{\alpha}$ and the nitro group linked aromatic carbon; whereas the EDD concentrates mostly on the three $-\mathrm{NO}_{2}$ moieties (Fig. 11). Obviously, the EDD map and HDD map separated entirely for $\mathrm{L}^{3-}{ }^{3-}$, indicating a CT type excitation. This is also evidenced by the large $\Delta r$ index $(6.095 \AA)$ and $D$ value (2.218 ̊).

\section{Conclusions}

In summary, a series of asymmetric tris-urea receptors with EWG and EDG urea receptors L1-L4 has been prepared and characterized. These receptors with a EWG substituent showed a naked-eye detection and discrimination of fluoride and hydroxide anions over other anions like chloride, bromide, iodide, dihydrogen phosphate, hydrogen sulphate, acetate, nitrate, perchlorate and perrhenate in DMSO medium. We have experimentally confirmed that stepwise deprotonation of the three urea $\mathrm{N}-\mathrm{H}$ protons linked to the phenyl ring upon the addition of excess $\mathrm{F}^{-}$or $\mathrm{OH}^{-}$ions is responsible for these vivid colour development. This visible change in colours associates well with the UV-Vis experimental results that a new intense band with bathochromic shift developed gradually on the addition of fluoride or hydroxide anions to receptor. In addition, NMR titrations also proved that proton transfer takes place in the presence of excess $\mathrm{F}^{-}$ions, with formation of $\mathrm{HF}_{2}{ }^{-}$ion, the most-stable H-bond complex that fluoride anion can form. On the other hand, DFT calculations displayed that the deprotonation of one $\mathrm{N}-\mathrm{H}_{\mathrm{c}}$ and two $\mathrm{N}-\mathrm{H}_{\mathrm{a}}\left(\right.$ or $\left.\mathrm{N}-\mathrm{H}_{\mathrm{a}^{\prime}}\right)$ protons linked to aromatic ring in energies is more favourable than that of the two $\mathrm{N}-\mathrm{H}_{\mathrm{b}}\left(\right.$ or $\left.\mathrm{N}-\mathrm{H}_{\mathrm{b}^{\prime}}\right)$ protons linked to alkyl group when excess fluoride or hydroxide anions exists. TDDFT results implied that a lower excitation energy for anionic receptors compared with their neutral ones and charge transfer mostly from the urea subunits to nitro moieties in the excited state was responsible for the bathochromic absorption, reflecting the colorimetric visible changes. More importantly, our results indicated that asymmetric phenyl urea substituted by EWG as simple highly coloured CT chromophore have potential as naked-eye sensor for $\mathrm{F}^{-}$and $\mathrm{OH}^{-}$ions in DMSO solution. We are currently investigating EWG derived asymmetric multi-ureas frameworks as simple visible colorimetric sensors for ions recognition.

\section{Conflicts of interest}

There are no conflicts to declare.

\section{Acknowledgements}

This work was supported by the National Natural Science Foundation of China (grant numbers 21501123, 11775153, 11575122). We would like to acknowledge the "Comprehensive Training Platform of Specialized Laboratory, College of Chemistry, Sichuan University" for IR, NMR and XRD analyses. We appreciate the help from Dr Yue Qi for X-ray diffraction singlecrystal measurements.

\section{Notes and references}

1 J. L. Sessler, P. A. Gale and W.-S. Cho, Anion Receptor Chemistry: Monographs in Supramolecular Chemistry, RSC, Cambridge, UK, 2006.

2 M. S. Vickers and P. D. Beer, Chem. Soc. Rev., 2007, 36, 211225.

3 P. D. Beer and P. A. Gale, Angew. Chem., Int. Ed., 2001, 40, 486-516.

4 R. G. Van Kesteren, S. A. Duursma, W. J. Visser, V. Van der Sluys and O. Backer Dicks, Metab. Bone Dis. Relat. Res., 1982, 4, 31-37.

5 K. Müller, C. Faeh and F. Diederich, Science, 2007, 317, 18811886.

6 C. I. Lin, S. Selvi, J. M. Fang, P. T. Chou, C. H. Lai and Y. M. Cheng, J. Org. Chem., 2007, 72, 3537-3542.

7 P. A. Gale, Chem. Commun., 2011, 47, 82-86.

8 J.-M. Lehn, Supramolecular Chemistry: Concepts and Perspectives, VCH, Weinheim, 1995.

9 Z. Xu, H. Ge, X. Han, S. H. Liu, X. G. Meng and J. Yin, Tetrahedron, 2017, 73, 6386-6391.

10 V. Amendola, D. Esteban-Gómez, L. Fabbrizzi and M. Licchelli, Acc. Chem. Res., 2006, 39, 343-353.

11 M. N. Hoque and G. Das, CrystEngComm, 2017, 19, 13431360.

12 V. B. Bregović, N. Basarić and K. Mlinarić-Majerski, Coord. Chem. Rev., 2015, 295, 80-124.

13 A. F. Li, J. H. Wang, F. Wang and Y. B. Jiang, Chem. Soc. Rev., 2010, 39, 3729-3745.

14 M. Boiocchi, L. D. Boca, D. E. Gómez, L. Fabbrizzi, M. Licchelli and E. Monzan, J. Am. Chem. Soc., 2004, 126, 16507-16514.

15 D. Esteban-Gómez, L. Fabbrizzi and M. Licchelli, J. Org. Chem., 2005, 70, 5717-5720.

16 P. Bose and P. Ghosh, Chem. Commun., 2010, 46, 2962-2964.

17 J. Kang, Y. J. Lee, S. Lee, J. H. Lee, J. J. Park, Y. Kim, S. J. Kim and C. Kim, Supramol. Chem., 2010, 22, 267-273.

18 E. J. Cho, J. W. Moon, S. W. Ko, J. Y. Lee, S. K. Kim, J. Yoon and K. C. Nam, J. Am. Chem. Soc., 2003, 125, 12376-12377.

19 E. J. Cho, B. J. Ryu, Y. J. Lee and K. C. Nam, Org. Lett., 2005, 7, 2607-2609.

20 D. A. Jose, D. K. Kumar, B. Ganguly and A. Das, Org. Lett., 2004, 6, 3445-3448.

21 S. Kondo, H. Sonoda, T. Katsu and M. Unnob, Sens. Actuators, B, 2011, 160, 684-690.

22 B. Garg, T. Bisht and S. M. S. Chauhan, Sens. Actuators, B, 2012, 168, 318-328.

23 M. Arunachalam and P. Ghosh, Chem. Commun., 2011, 47, 8477-8492.

24 R. Custelcean, Chem. Commun., 2013, 49, 2173-2182.

25 S. K. Dey, A. Basu, R. Chutia and G. Das, RSC Adv., 2016, 6, 26568-26589.

26 B. P. Hay, T. K. Firman and B. A. Moyer, J. Am. Chem. Soc., 2005, 127, 1810-1819.

27 R. Custelcean, B. A. Moyer and B. P. Hay, Chem. Commun., 2005, 5971-5973. 
28 D. A. Jose, D. K. Kumar, B. Ganguly and A. Das, Inorg. Chem., 2007, 46, 5817-5819.

29 I. Ravikumar, P. S. Lakshminarayanan, M. Arunachalam, E. Suresh and P. Ghosh, Dalton Trans., 2009, 4160-4168.

30 R. Dutta, P. Bose and P. Ghosh, Dalton Trans., 2013, 42, 11371-11374.

31 R. Dutta, S. Chakraborty, P. Bose and P. Ghosh, Eur. J. Inorg. Chem., 2014, 25, 4134-4143.

32 R. Custelcean and P. Remy, Cryst. Growth Des., 2009, 9, 19851989.

33 A. Pramanik, B. Thompson, T. Hayes, D. R. Powell, P. V. Bonnesen, P. V. Bonnesen, E. D. Ellis, K. S. Lee, H. Yu and M. A. Hossain, Org. Biomol. Chem., 2011, 9, 4444-4447.

34 A. Pramanik, D. R. Powell, B. M. Wong and M. A. Hossain, Inorg. Chem., 2012, 51, 4274-4284.

35 J. R. Hiscock, P. A. Gale and M. J. Hynes, Supramol. Chem., 2012, 24, 355-360.

36 S. K. Dey, R. Chutia and G. Das, Inorg. Chem., 2012, 51, 17271738.

37 R. Chutia, S. K. Dey and G. Das, Cryst. Growth Des., 2013, 13, 883-892.

38 J. Zhao, D. Yang, Y. Zhao, L. Cao, Z. Zhang, X.-J. Yang and B. Wu, Dalton Trans., 2016, 45, 7360-7365.

39 M. Emami Khansari, M. H. Hasan, C. R. Johnson, N. A. Williams, B. M. Wong, D. R. Powell, D. R. Powell, R. Tandon and M. A. Hossain, ACS Omega, 2017, 2, 90579066.

40 C. Huang, R. Y. Wang, X. Shu, Y. Qi, S. J. Li and C. Q. Xia, Acta Crystallogr., Sect. E: Crystallogr. Commun., 2017, 73, 13161319.

41 O. V. Dolomanov, L. J. Bourhis, R. J. Gildea, J. A. K. Howard and H. Puschmann, J. Appl. Crystallogr., 2009, 42, 339-341.

42 G. M. Sheldrick, Acta Crystallogr., Sect. A: Found. Adv., 2015, 71, 3-8.

43 G. M. Sheldrick, Acta Crystallogr., Sect. C: Struct. Chem., 2015, 71, 3-8.

44 M. J. Frisch, G. W. Trucks, H. B. Schlegel, G. E. Scuseria, M. A. Robb, J. R. Cheeseman, G. Scalmani, V. Barone, B. Mennucci, G. A. Petersson, H. Nakatsuji, M. Caricato, X. Li, H. P. Hratchian, A. F. Izmaylov, J. Bloino, G. Zheng, J. L. Sonnenberg, M. Hada, M. Ehara, K. Toyota, R. Fukuda, J. Hasegawa, M. Ishida, T. Nakajima, Y. Honda, O. Kitao, H. Nakai, T. Vreven, J. A. Montgomery Jr., J. E. Peralta, F. Ogliaro, M. Bearpark, J. J. Heyd, E. Brothers, K. N. Kudin, V. N. Staroverov, R. Kobayashi, J. Normand, K. Raghavachari, A. Rendell, J. C. Burant, S. S. Iyengar, J. Tomasi, M. Cossi, N. Rega, J. M. Millam, M. Klene, J. E. Knox, J. B. Cross, V. Bakken, C. Adamo, J. Jaramillo, R. Gomperts, R. E. Stratmann, O. Yazyev, A. J. Austin, R. Cammi, C. Pomelli, J. W. Ochterski, R. L. Martin, K. Morokuma, V. G. Zakrzewski, G. A. Voth,
P. Salvador, J. J. Dannenberg, S. Dapprich, A. D. Daniels, Ö. Farkas, J. B. Foresman, J. V. Ortiz, J. Cioslowski and D. J. Fox, Gaussian 09, Revision D. 01, Gaussian Inc., Wallingford, CT, 2013.

45 Y. Zhao and D. G. Truhlar, Theor. Chem. Acc., 2008, 120, 215241.

46 R. Krishnan, J. S. Binkley, R. Seeger and J. A. Pople, J. Chem. Phys., 1980, 72, 650-654.

47 M. Cossi, V. Barone, R. Cammi and J. Tomasi, Chem. Phys. Lett., 1996, 255, 327-335.

48 V. Barone, M. Cossi and J. Tomasi, J. Comput. Chem., 1998, 19, 404-417.

49 F. Weigend and R. Ahlrichs, Phys. Chem. Chem. Phys., 2005, 7, 3297-3305.

50 J. Zheng, X. Xu and D. G. Truhlar, Theor. Chem. Acc., 2011, 128, 295-305.

51 C. Adamo and V. Barone, J. Chem. Phys., 1999, 110, 61586170.

52 T. Lu and F. Chen, J. Comput. Chem., 2012, 33, 580-592.

53 W. Humphrey, A. Dalke and K. Schulten, J. Mol. Graphics, 1996, 14, 33-38.

54 Y. Hao, C. Jia, S. Li, X. Huang, X. J. Yang, C. Janiak and B. Wu, Supramol. Chem., 2012, 24, 88-94.

55 R. Zhang, Y. Zhao, J. Wang, L. Ji, X. J. Yang and B. Wu, Cryst. Growth Des., 2014, 14, 544-551.

56 V. K. Bhardwaj, S. Sharma, N. Singh, M. S. Hundal and G. Hundal, Supramol. Chem., 2011, 23, 790-800.

57 J. Y. Lee, E. J. Cho, S. Mukamel and K. C. Nam, J. Org. Chem., 2004, 69, 943-950.

58 F. G. Bordwell, Acc. Chem. Res., 1988, 21, 456-463.

59 I. G. Shenderovich, P. M. Tolstoy, N. S. Golubev, S. N. Smirnov, G. S. Denisov and H.-H. Limbach, J. Am. Chem. Soc., 2003, 125, 11710-11720.

60 E. G. Hohenstein, S. T. Chill and C. D. Sherrill, J. Chem. Theory Comput., 2008, 4, 1996-2000.

61 Y. Zhao and D. G. Truhlar, J. Chem. Theory Comput., 2008, 4, 1849-1868.

62 Y. Zhao and D. G. Truhlar, Acc. Chem. Res., 2008, 41, 157-167. 63 L. P. Wolters, P. Schyman, M. J. Pavan, W. L. Jorgensen, F. M. Bickelhaupt and S. Kozuch, Wiley Interdiscip. Rev.: Comput. Mol. Sci., 2014, 4, 523-540.

64 L. S. Evans, P. A. Gale, M. E. Light and R. Quesada, Chem. Commun., 2006, 965-967.

65 C. S. Wilcox, E. Kim, D. Romano, L. H. Kuo, A. L. Burt and D. P. Curran, Tetrahedron, 1995, 51, 621-634.

66 Supramolecular.org,http://supramolecular.org/.

67 V. Amendola, L. Fabbrizzi and L. Mosca, Chem. Soc. Rev., 2010, 39, 3889-3915.

68 C. A. Guido, P. Cortona, B. Mennucci and C. Adamo, J. Chem. Theory Comput., 2013, 9, 3118-3126. 